\title{
Facility Overview for \\ Commercial Application of Selected Rocky Flats Facilities
}

RECEIVED Report No. 96-910 JUL 02 ROP

$0.8 T 1$ Performed Under Contract No. KH 603563MW-WLB-289-916

November 1996

Submitted to: Kaiser-Hill Company, LLC

Prepared by:

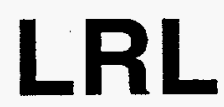

Energy Services Incorporated 13380 Pantera Road San Diego, California 92130 Voice • 619・259・9964 Fax $\bullet 619 \bullet 792 \cdot 5867$ 


\section{DISCLAMMIER}

Portions of this document may be illegible in electronic image products. Images are produced from the best avallable original document. 
Table of Contents

\section{Executive Summary Page 1}

II. Current Project Description Page 3

2.1 Introduction Page 3

2.2 National Conversion Pilot Project Page 3

2.3 Site Page 5

2.4 Buildings Page 6

2.5 Equipment and Capabilities Page $\mathbf{1 5}$

2.6 Site Services Page 21

2.7 Human Resources Page $\mathbf{2 3}$

2.8 Environmental Page $\mathbf{2 5}$

III. Potential Products and Markets Page 27

3.1 Commercial Markets Page 27

3.2 Government Markets Page 27

3.3 Process Verification Support Page $\mathbf{3 0}$

Appendix A: Environmental Remediation Standards Page 31

Appendix B: Environmental Release History of Rocky Flats Plant

Buildings 865 and $883 \quad$ Page 45

Appendix C: DOE Scrap Metal Inventory Page 63 


\section{List of Figures}

Location of Rocky Flats Site. Page 7

2

Location of Buildings 865, 883, 444-7.

Page 8

3

Layout of Building 865. Page 9

4

Layout of Building $883 . \quad$ Page 10

\section{DISCLAIMER}

This report was prepared as an account of work sponsored by an agency of the United States Government. Neither the United States Government nor any agency thereof, nor any of their employees, makes any warranty, express or implied, or assumes any legal liability or responsibility for the accuracy, completeness, or usefulness of any information, apparatus, product, or process disclosed, or represents that its use would not infringe privately owned rights. Reference herein to any specific commercial product, process, or service by trade name, trademark, manufacturer, or otherwise does not necessarily constitute or imply its endorsement, recommendation, or favoring by the United States Government or any agency thereof. The views and opinions of authors expressed herein do not necessarily state or reflect those of the United States Government or any agency thereof. 


\section{List of Photographs}

$1 \quad$ Building 865. Page 6

$2 \quad$ Building 883. Page 6

3 Overhead View of Equipment in Building 883. Page 15

4 Loewy Rolling Mills. Page 16

$5 \quad$ Large Hydraulic Press. Page 17

6 Large Hydraulic Press. Page 17

$7 \quad$ USI Clearing Press. Page 18

8 Roll Grinder. Page 19

9 Shear. Page 19

10 Rotary Furnace. Page 20

11 Extrusion Press. Page 21 
nसे

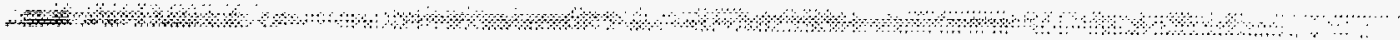

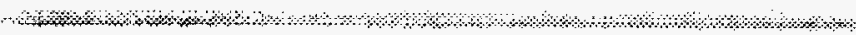

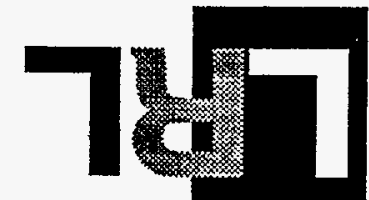

mom

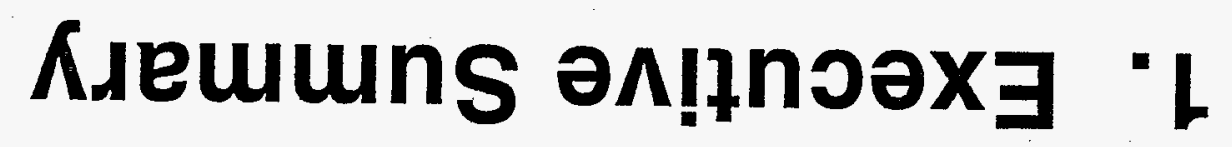

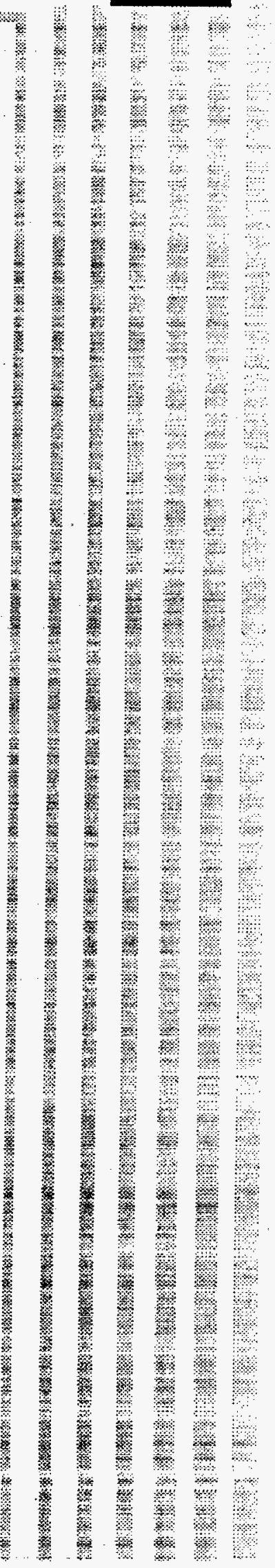




\section{Section I}

\section{Executive Summary}

This document was prepared to assist the DOE and the Community Reuse Organization (CRO) in finding alternate uses for certain buildings and equipment on the Rocky Flats site that are excess to government needs. It describes the buildings and equipment, their past use and current condition, and the potential markets for products that might be manufactured using materials from DOE's surplus inventory.

The U.S. Department of Energy (DOE) facility at Rocky Flats, a 6,265 acre site approximately 16 miles northwest of Denver, Colorado; between Boulder and Golden, was built to support plutonium processing, and plutonium, uranium, and beryllium fabrication for the U.S. nuclear weapons program. Plant construction began in 1951, and operations began in 1952. The main plant occupies a 384-acre complex consisting of 436 buildings and facilities with over 3,000,000 square feet of floor space for manufacturing, chemical processing, laboratory, and support activities.

The nuclear materials mission was terminated in 1992, and in 1994 the Rocky Flats mission and installation name were officially changed to the Rocky Flats Environmental Technology Site (RFETS). The new mission is to: "Manage waste and materials, clean up and convert the Rocky Flats site to beneficial use in a manner that is safe, environmentally and socially responsible, physically secure, and cost-effective."

DOE is currently in the process of developing a plan to achieve clean-up and closure of most of the RFETS by 2006. The local CRO and stakeholder organization, the Rocky Flats Local Impact Initiative (RFLII), has been, and will be, actively involved in this transition.

In 1993, the Secretary of Energy approved an economic conversion demonstration project, the National Conversion Pilot Project (NCPP), at Rocky Flats. The mission of the NCPP is "to explore and demonstrate, at the Rocky Flats site, the feasibility of economic conversion at Department of Energy facilities." The NCPP consists of three stages. Stage I, (completed) involved characterization of the condition of the four buildings (Buildings 444,447, 865, and 883) to be used for the NCPP and planning for the subsequent stages. The Stage II effort, at full funding, 
involved the cleanup of the four buildings listed in preparation for the Stage III demonstration. Stage II, in addition to cleanup involved (1) declassification of existing hardware in the buildings in preparation for recycling it and (2) a limited amount of process verification to demonstrate suitability of the equipment within the buildings for producing products that can be made with recycled metals in Stage III. The three materials to be considered for recycling were low level Radioactive Scrap Metal (RSM), Depleted Uranium (DU), and Beryllium (Be).

To date in Stage II, the cleanup in buildings 865 and 883 is scheduled to be completed by May 1, 1996, several market analyses for the three scrap materials have been conducted, and a process verification effort is under way to build nuclear waste storage containers from low level radioactive scrap material (RSM).

All radioactive cleanup to a level below prescribed Interim Measure/ Interim Remedial Action (IM/IRA) worker safety limits, as defined later in this report, will be accomplished prior to the leasing of facilities to a private corporation. The commercial contractor selected will have the use of the buildings, equipment, and utilities, defined in this report, on lease terms and conditions to be negotiated with DOE.

The lease would be for an interim period until final decisions can be made on the final status of all of the buildings and infrastructure at the RFETS. The personnel presently conducting the Stage Il cleanup operations and the "scrap material process verification" effort as noted in Section 3.3 are also available to the Stage III contractor, subject to successful negotiations between the contractor and each individual.

The purpose of RFLII's Request For Interest (RFI), as issued in conjunction with DOE, was to solicit interest from commercial corporations for utilizing buildings 865 and 883 , and the equipment contained within each building, for a commercial venture. This would be a somewhat modified version of NCPP Stage III as originally conceived; only two of the four buildings will be utilized initially, but will be considered for any potential application, not just metal recycling operations. All potential ideas or applications, to include those studied in the "process verification effort" of Stage II, will be considered. The leasee would be required to obtain all necessary regulatory approvals, permits, or licenses for his proposed applications. Although the initial effort envisions the use of only buildings 865 and 883 , it is possible that buildings 444 and 447 , and the equipment contained in each, may become available at a later date. 


\section{Current Project Description}



Energy Services Incorporated 


\section{Section 2}

\section{Current Project Description}

\subsection{Introduction}

The purpose of this Facility Overview is to support RFLII's RFI, to solicit interest from commercial corporations for utilizing buildings 865 and 883 , and the equipment contained within each building, for a commercial venture.

In the following sections, this document describes the Rocky Flats Site, the buildings available for lease, the equipment within these buildings, the site services available to a tenant, the human resources available to support operations in buildings 865 and 883 , and the environmental condition of the buildings and property.

In addition, a brief description is provided of the work performed to date to explore the potential products that might be manufactured in Buildings 865 and 883 , and the markets for these products.

\subsection{National Conversion Pilot Project}

Preparation of the buildings for commercial use was performed under the National Conversion Pilot Project (NCPP), sponsored by DOE. The mission of NCPP is "to explore and demonstrate, at the Site, the feasibility of economic conversion at Department of Energy facilities."

Economic conversion is defined as the conversion of facilities and equipment owned by the Federal government to the production of goods by private firms for profit. The NCPP mission is consistent with the current Rocky Flats Site mission, which is to "manage waste and materials, clean up and convert the Site to beneficial use in a manner that is safe, environmentally and socially responsible, physically secure and cost effective."

The NCPP was authorized in December 1993 by Secretary of Energy O'Leary to proceed in three distinct stages with a review and positive decision required at the end of each stage before proceeding to the next. The NCPP is being conducted through a Cooperative Agreement, which was signed April 1, 1994, between the U.S. Department of Energy (DOE) and Manufacturing Sciences Corporation (MSC). 
NCPP is an important step in implementing the Site mission because conversion of the Site facilities to beneficial use is specifically enunciated in the mission statement. This pilot project involving Buildings 865 and 883 is the first step in defining how the Rocky Flats Field Office will implement that part of its mission.

The NCPP has been divided into three stages, with decision points at the ends of Stages I and II and periodically during Stage III, to help ensure careful consideration of project feasibility and the opportunity for feedback from Stakeholders. At the end of each stage, the project could be revised or terminated, and DOE will only proceed with future project stages with the support of regulatory agencies and the acceptance of the community.

Stage I, which officially began on April 1, 1994, was the planning step in the NCPP where information concerning facilities proposed for conversion was assembled. This information pertained to building characterization and assessment activities, planning for cleanup, further site characterization, and operational assessment activities. Stage I also included additional market analysis; the development of a staffing and training plan, a regulatory oversight plan, and support services agreements; and appropriate regulatory reviews for Stage II. All of these documents are available for review in the Reading Room (see Section 3.2) maintained by Kaiser-Hill. A decision to proceed to Stage II was made following public outreach activities that obtained feedback on the project.

Stage II, the cleanup, declassification and refurbishment step designed to make Building 865,883 and others ready for commercial operations, involves additional building characterization, and building cleanup activities. Stage II activities are now nearing completion for Buildings 865 and 883 .

Stage III will make these facilities available for commercial operations through a competitive process. As currently envisioned, Stage IIl will involve a five year lease for the facilities, with a five year extension option. The RFLII request for expressions of interest was made in the context of the competitive selection process for NCPP Stage III.

\section{NCPP Steering Committee}

Central to the conduct of the Stage II NCPP is a steering committee comprised of a representative from those organizations most critically impacted by, or who have critical influence over, the outcomes of the project. These include: 
- The Colorado Governor's Office, represented by the Defense Conversion Director from the Colorado Office of Business Development.

- The Colorado Department of Health and Environment

- The U.S. Department of Energy (DOE)

- The U.S. Environmental Protection Agency

- Kaiser-Hill, LLC, the Management and Integration Contractor

- Manufacturing Sciences Corporation (MSC), the NCPP Stage II Operator

- The Rocky Flats Local Impacts Initiative (RFLII), a Community Reuse Organization representing local stakeholder groups.

\subsection{Site}

The buildings being offered for use are located at the Rocky Flats Environmental Technology Site. Figure 1 shows the location of the site in Colorado. Figure 2 shows the location of Buildings 865 and 883 on the Rocky Flats Site.

The RFETS is located in northern Jefferson County, Colorado, approximately 16 miles northwest of downtown Denver (see Figure 1). The site consists of approximately 6,265 acres of federally owned land. The RFETS property is approximately 3 miles (north-south) by 4 miles (eastwest). Buildings are located within an area of 384 acres, known as the RFETS Industrial Area.

The RFETS is a government-owned, contractor-operated facility. It is part of a nationwide complex that performed nuclear weapons research, development, production, and reprocessing in the past, and is administered by the DOE Rocky Flats Field Office (DOE-RFFO). The Management and Integration (MEI) contractor for the RFETS is KaiserHill, LLC. The facility has been in operation since 1952, manufacturing components for nuclear weapons and conducting plutonium reprocessing. The RFETS fabricated components from plutonium, uranium, beryllium, and stainless steel. Historically, production activities have included metal refining, fabrication, machining, and assembly. Both radioactive and hazardous wastes were generated in the process. Current waste handling practices involve on-site and off-site recycling of hazardous materials, onsite storage of wastes, and off-site disposal of solid radioactive wastes at other DOE facilities.

As noted above, DOE is currently developing a plan to clean up the site, and to cease most of its functions at RFETS by the year 2006. These activities include treating and shipping waste off site, demolition of most 
site facilities, cleaning radioactively contaminated soils to limits acceptable for open space, and consolidating all plutonium that cannot be shipped to other sites into a new interim storage facility at Rocky Flats. The interim storage of plutonium is projected to be terminated by the year 2020 .

\section{$2.4 \quad$ Buildings}

In this section a description of the available facilities and their past history is provided. The two buildings are shown in Photos 1 and 2 below. Layouts of the two buildings that are available for immediate Stage III use, Building 865 and Building 883, are shown in Figures 3 and 4.



Photo 1 - Building 865

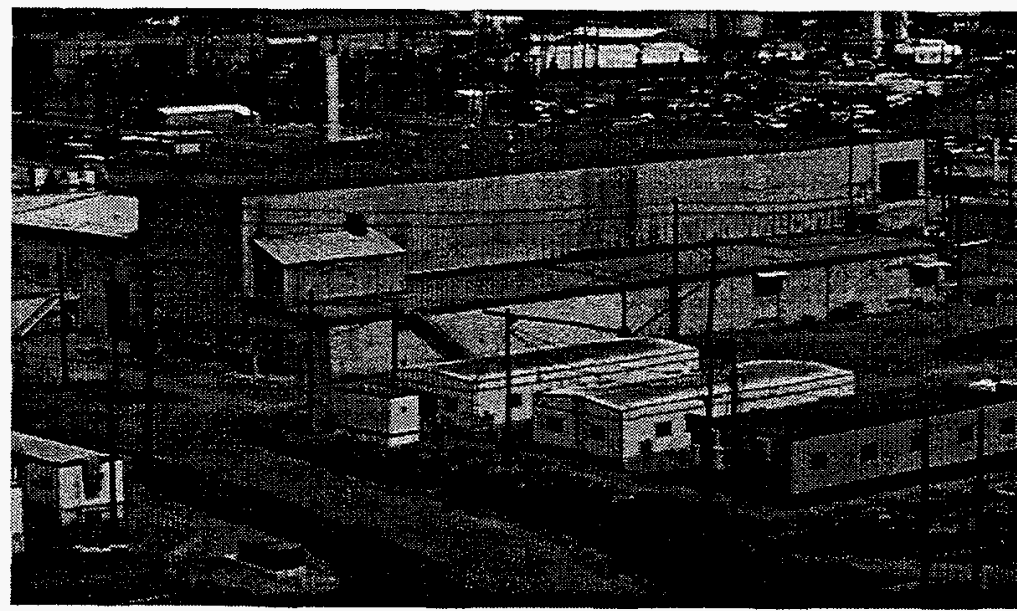

Photo 2 - Building 883 




Figure 1. Location of Rocky Flats Site. 


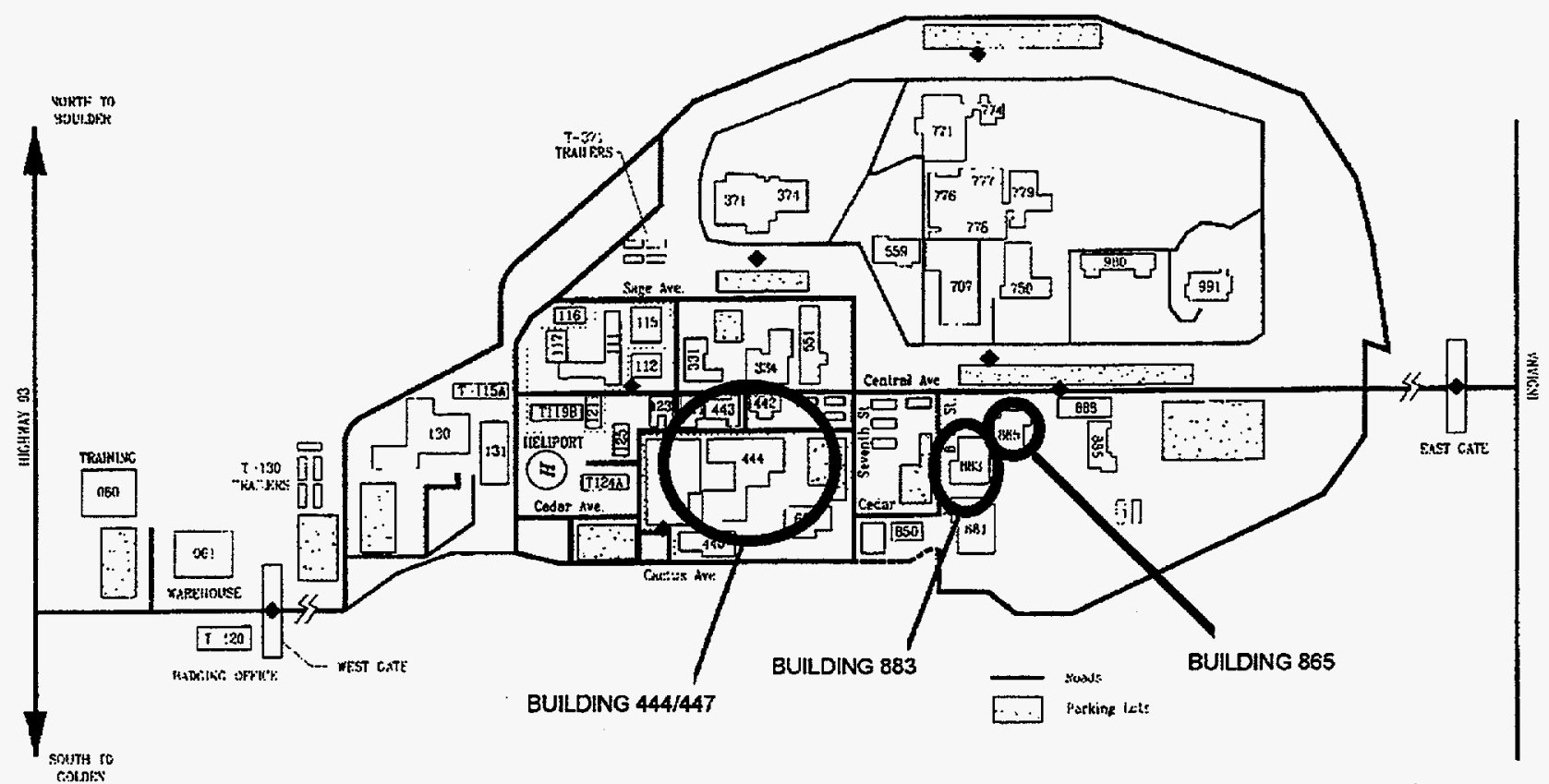

vor To scet.l:

Figure 2. Location of Buildings 865, 883, 444-7. 


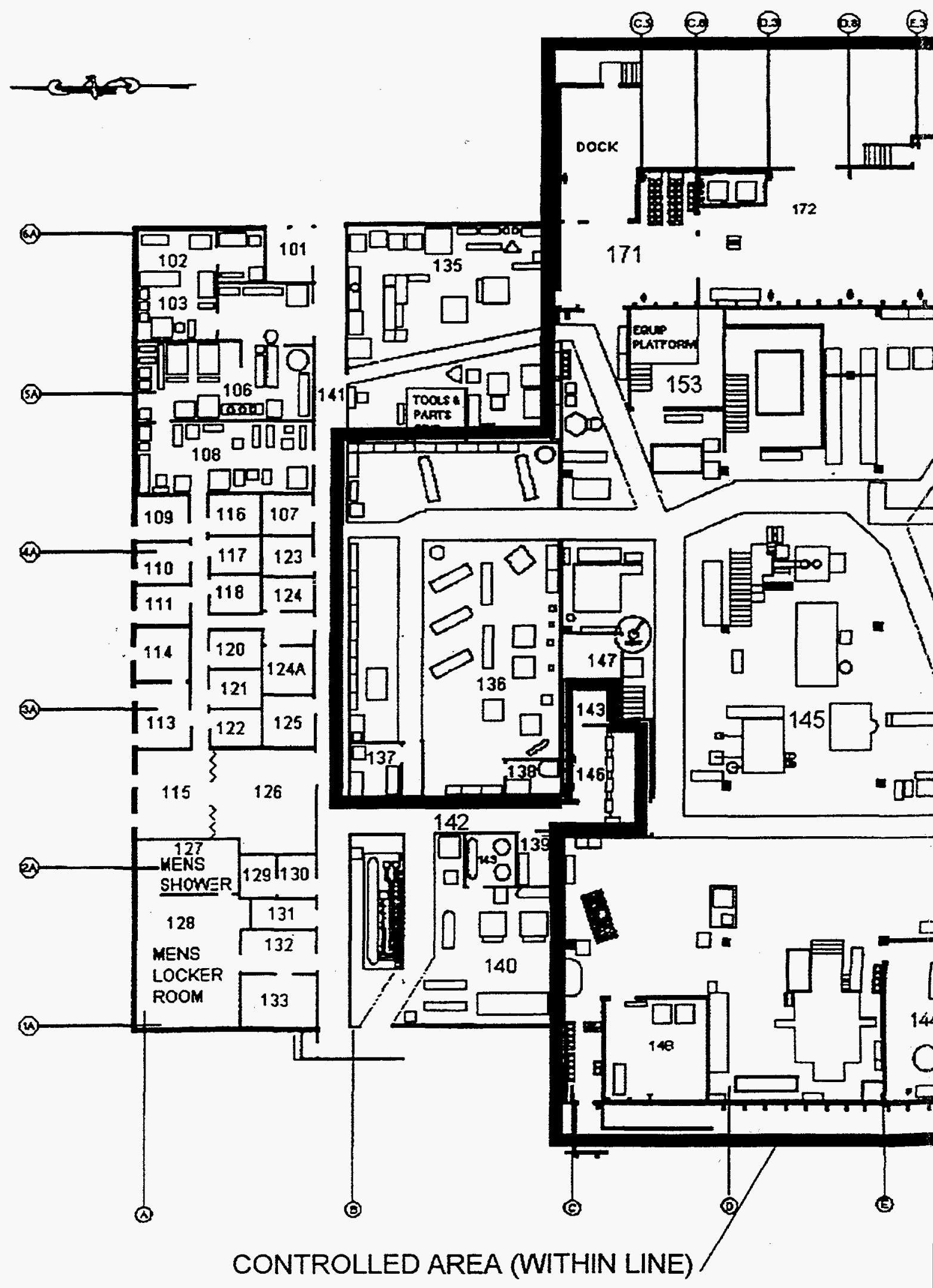

Figure 3. Layou 
BUILDING 883 FINAL EQUIPMENT

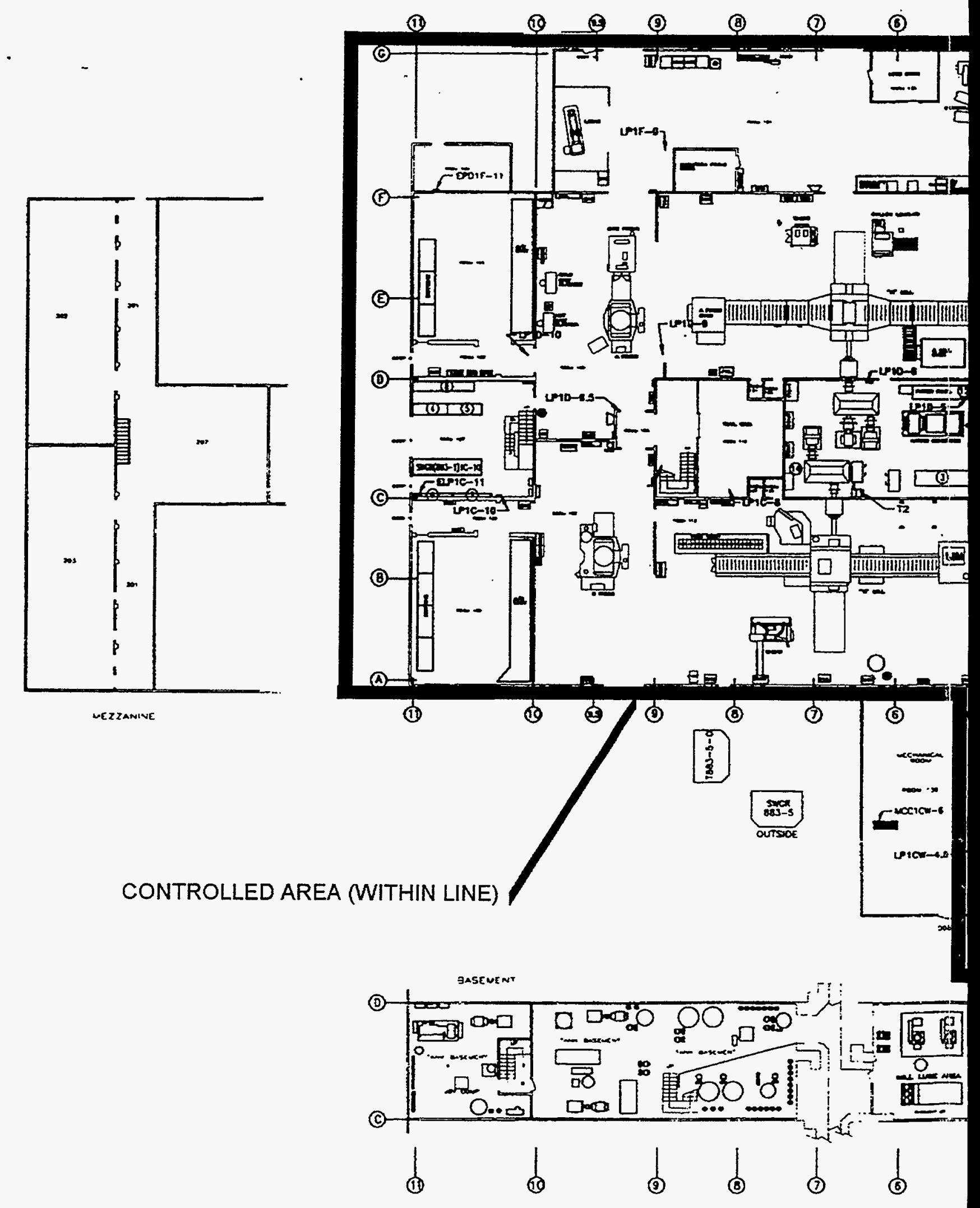

Figure 4. Layout 
The buildings that are available were previously used to produce parts for nuclear weapons, before the RFETS mission changed. There are four buildings associated with the NCPP: 444, 447, 865, and 883 . Buildings 444 and 447 , however, are contiguous buildings and are usually referred to as one building, Building $444 / 7$. Building $444 / 7$ is described briefly in this section since it may become available at a later date. However, at this time $444 / 7$ is not a part of the RFLIl solicitation. Specific information on the major pieces of equipment is provided in Section 2.5.

\section{Building 865}

Building 865 is located in the southeast area of the RFETS Industrial Area. Figure 3 shows the floor plan of Building 865 . The building is a one-story structure built in 1972, with a floor area of about 38,000 square feet. However, the shop area is a high bay, twice as high as the laboratoryoffice section. The shop area also has a small mezzanine floor. The building is primarily vertical, reinforced concrete twin-tee panels supported by a precast concrete framework. The laboratory-office portion is constructed of concrete block.

Building 865 has been primarily used for materials and process development operations. Operational capabilities included metal rolling, shearing, forging, extruding, swaging, pressing, grinding, heat treating, vacuum-induction casting, and vacuum-arc casting. Inspection, testing, shipping, and receiving also took place in Building 865 . The metals that were worked in the building were primarily: depleted uranium, various alloys of depleted uranium, beryllium, tool steel, stainless steel, and aluminum. Other less common metals such as gold, iridium, niobium, platinum, silver, tantalum, titanium, and tungsten were processed as required. No plutonium or enriched uranium was processed in the building.

The building function continues to be supported by several ancillary facilities. Building 827 provides emergency electrical power, Building 863 provides power for the extrusion press, Building 866 houses liquid effluent storage facilities, and Buildings 867 and 868 house exhaust fans and filters/plenums. These buildings are also included in the planned solicitation.

As shown in Figure 3, the high-bay area contains the large metal working equipment including a rolling mill, extrusion press, hydraulic press, and machine shop. The laboratory-office area contains administrative offices, a maintenance shop, and a metallographic laboratory. 


\section{Building 883}

Building 883 is located adjacent to Building 865 (see Figure 2). Building 883 is a combined one-and two-story structure, built in 1957, with a partial basement and a floor area of 60,500 square feet. Building 883 is constructed of a steel frame with corrugated exterior panels and some concrete exterior walls. The floors are concrete with limited areas covered with tile or short pile carpet. The ceilings in the office areas are suspended, acoustical tile with integral lights. The process area ceilings are the exposed undersides of the roof. The roofs are the built-up type over steel decking, supported by structural steel.

The interior areas of the two-story portion of the building are high bays. There are only two, relatively small, second-floor areas. During its mission as part of the nuclear weapons program, Building 883 housed operations that processed both depleted and enriched uranium. These operations were once physically separated, with depleted uranium operations located in the east side of the building (commonly referred to in most Rocky Flats documents as the A side of 883), and enriched uranium operations located in the west side of the building (commonly referred to as the $B$ side of 883). In the early 1960's, the building was expanded to provide additional storage space. This addition, which includes Rooms 104 and 130 , is referred to as the annex.

Finally, in the early 1980 's, Building 883 was expanded to accommodate missions involving depleted uranium. This expansion, that includes Room 138 , is referred to as the $C$ side of the building.

Building 883 was used primarily for manufacturing and metallurgical operations. Operational capabilities included rolling, shearing, forging, pressing, welding, heat treating, cleaning, and weighing. Inspection, testing, shipping, and receiving also took place in Building 883. The metals worked were primarily depleted uranium, uranium alloys, stainless steel, and aluminum. Beryllium and other metals were, on occasion, worked in Building 883. No plutonium was processed in the building. However, there is the potential for minor actinide contamination of a duct in building 883. Tests are underway to determine the nature and extent of the contamination and the required decontamination steps. From 1957 until 1966, enriched uranium was processed in Building 883.

The plan view of Building 883 is shown in Figure 4. The central area of the building houses electrical generators, and power panels, including power distribution capability, (see Section 2.6, Site Services) for the metal processing equipment located on either side in the $A$ and $B$ sides of the 
building. The A side of the building contains a rolling mill, lathes, presses, and furnaces. The B side, of the building houses mills, a press, and some minor metal processing equipment. The $B$ side also includes a uranium storage area and several small rooms. The basement houses small items of equipment and a number of effluent handling vessels. Offices are located on both the first and second floors.

Building 883 historically was the primary facility at the Site for rolling and forming uranium blanks for final contour machining elsewhere at the plant. However, the NCPP mission for Building 883 is to convert it for use as a commercial facility. To implement the NCPP mission several processes may be maintained.

Rolling - The rolling process is located in Rooms 105 and 112. During this process, metal ingots are rolled to reduce the gauge and produce a desired grain structure. Process equipment includes furnaces and rolling mills (details of the equipment discussed on this page are included in Section 2.5). Metal pieces consisting of stainless steel, aluminum and beryllium are heated and rolled to achieve specific physical characteristics. The metal may be heated in a furnace prior to rolling. After heating, the metal is placed in one of two rolling mills and moved between the rollers until the desired thickness is obtained.

Forming - The forming process involves pressing metal blanks into specific shapes. Metals blanks maybe processed in a hard forming press or a hydroform. Occasionally, the blanks may be preheated in a furnace prior to forming.

Heat Treating - Heat treating takes place in Rooms 102, 104, and 105 Parts may be heat treated after rolling or forming to relieve stresses incurred by the rolling or forming processes.

Blanking and Trepanning - The blanking and trepanning process, located in Rooms 105 and 109, is conducted after parts have been rolled. Parts arrive at the blanking and trepanning process in the form of metal sheets. These metal sheets are then blanked or trepanned. Blanking consists of punch-pressing a shape from a metal sheet. Trepanning consists of cutting a shape from a metal sheet using a lathe.

Equipment used in this process includes a hydraulic press and lathe. The lathe utilizes a non-hazardous cutting oil (Trim Sol coolant) that is circulated through the equipment and over the part being trepanned. The coolant is wiped from the machined parts using rags before the parts are sent on to the forming process. Used Trim Sol coolant is placed into a low-level waste drum for disposal. 
Other support buildings for Building 883 include Building 879 that contains the filter plenum, and Building $883 \mathrm{~T}$, which contains the cooling towers.

\section{Building 444/7}

Building $444 / 7$ is located in the southwestern portion of the RFETS as shown in Figure 2.

Building 444 was built in 1953 , and is basically a single-story structure with a smaller second floor (mezzanine) and basement. Most of Building 444 consists of con- crete columns and tie beams supporting reinforced concrete exterior walls and roof. Other areas of the building have various combinations of concrete, concrete block, structural steel, corrugated cement, and steel. Building 444 has a floor area of about 160,000 square feet. In Building 444, the basement has an area of about 22,000 square feet, the first floor area is about 112,000 square feet, the second floor area is about 26,000 square feet, and the roof/third floor area is about 500 square feet.

Building 447 was added in 1957 and is corrugated cement on structural steel framing and has a floor area of about 21,000 square feet. The first floor has an area of about 16,500 square feet. The mezzanine has an area of about 4500 square feet.

Building 444/7 (and supporting buildings) were used for general metal fabrication and included a foundry and associated fabrication facilities, precision machine shops, tool engineering, production control, and nondestructive testing. Building 444/7 was capable of arc melting, induction casting, heat treating, electropolishing, precision machining, tool grinding, jig and fixture making, carbon mold machining, plating, cleaning, and assembling. Materials processed included depleted uranium, depleted uranium alloys, beryllium, aluminum, tool steels, special stainless steels, and graphite. Inspection, testing, shipping, and receiving also took place in Building 444/7. No plutonium or enriched uranium was processed in the facility. Building 447 contains a laboratory, beryllium heat treating area, and uranium casting area.

Support buildings for Building 444/7 include Building 427 - emergency generator, Building 449 - paint/oil storage, Building 453 - oil storage, and Buildings 454 and 457 - cooling towers. Building $444 / 447$ and its support buildings may be included in a future solicitation. 


\subsection{Equipment and Capabilities}

Most of the original equipment that was utilized in the initial Rocky Flats defense mission remains in Buildings 865 and 883. A description of the major equipment, that is available for application to alternative commercial missions, and photos of the equipment follow. Additional lathes, saws, and milling equipment are being considered for transfer to the lessee by DOE. Transfer of these items and other ancillary equipment (such as fork lifts, etc.) will be the subject of lease negotiations.

\section{Equipment Summary}

An overhead view of some of the equipment in Building 883 is shown below in Photo 3.

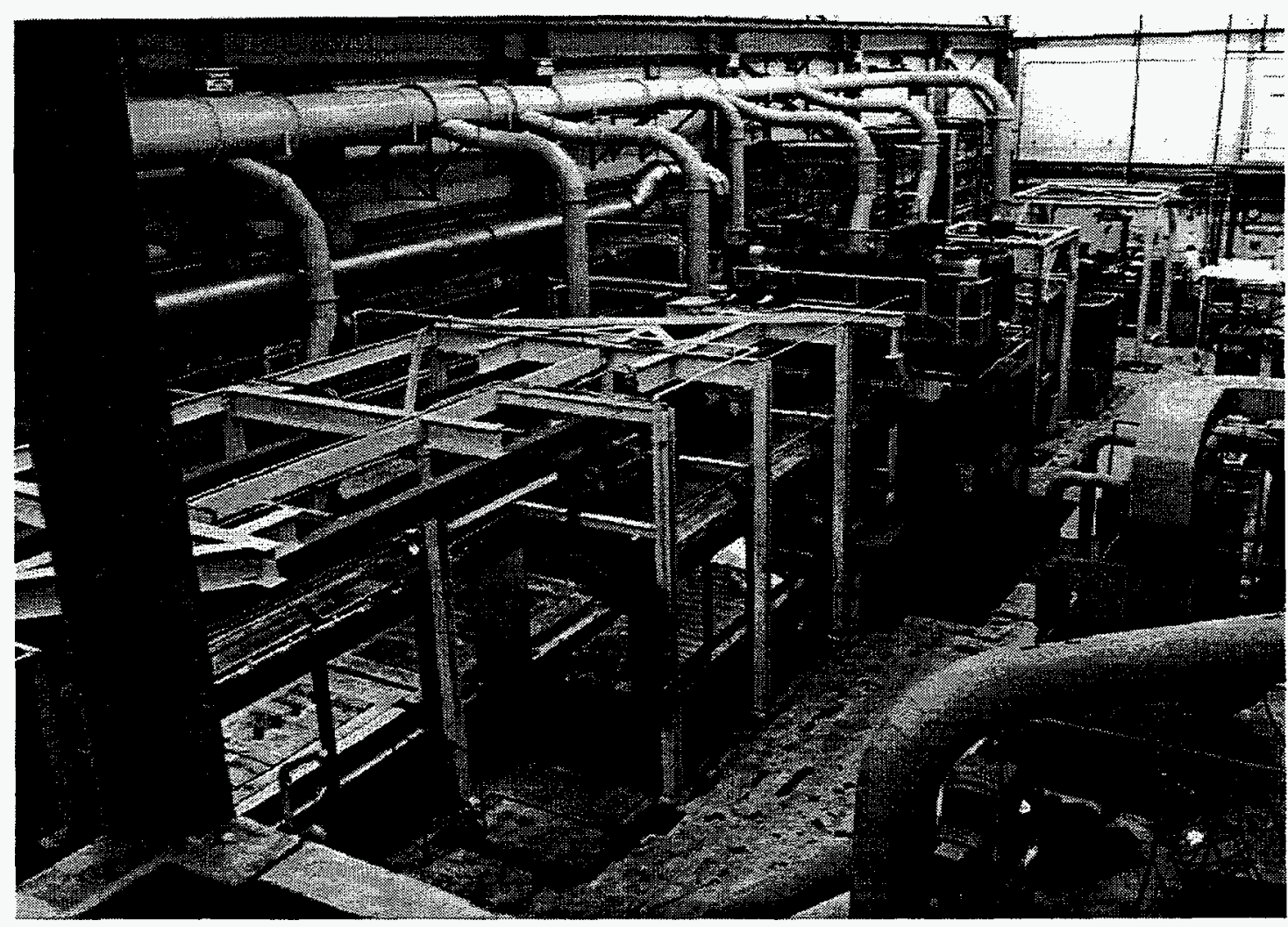

Photo 3. Overhead View of Equipment In Building 883

The equipment in Buildings 865 and 883 includes large rolling mills, hydraulic presses, a rollgrinder and furnaces, as shown in the following photos and described below: 


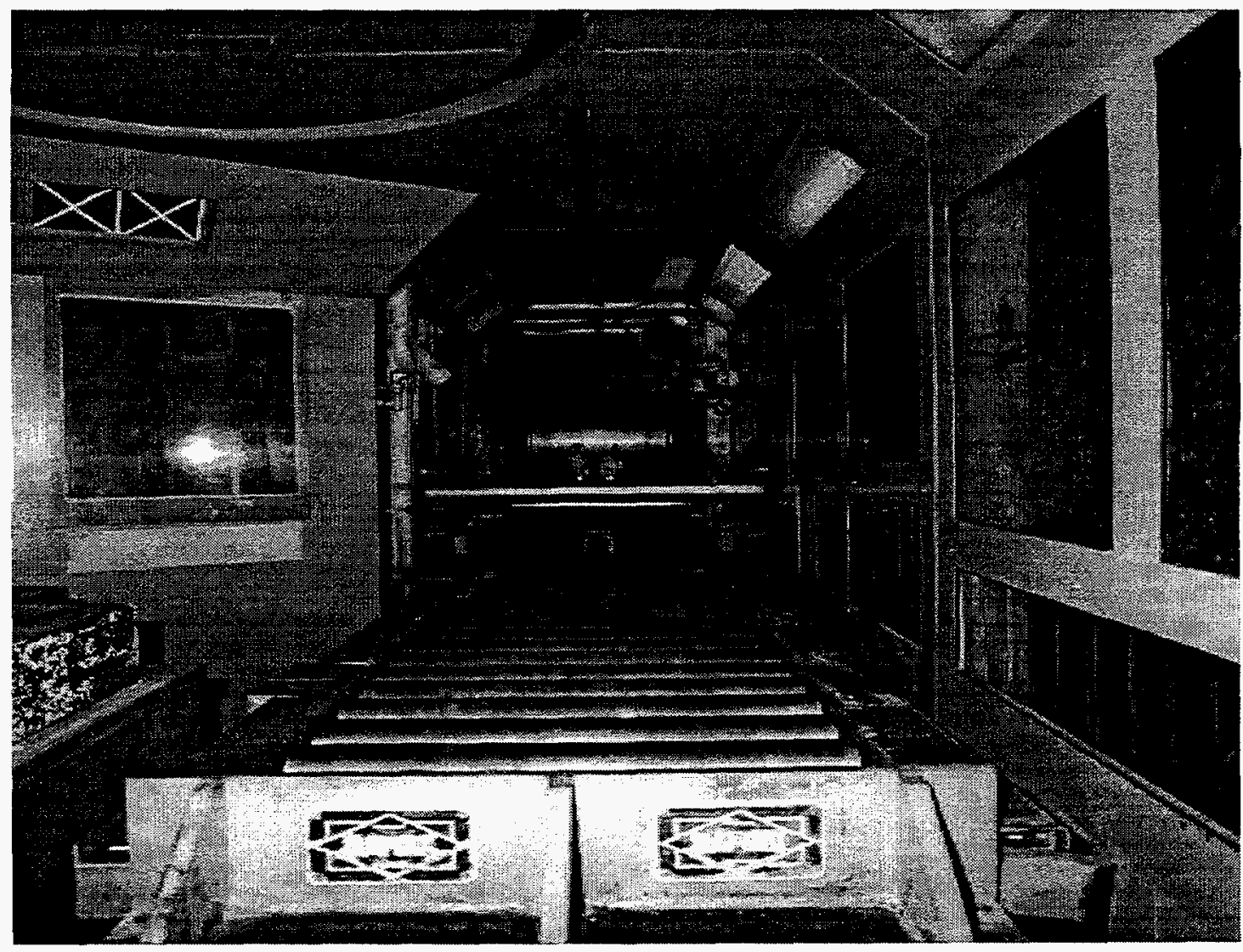

\section{Photo 4. Loewy Rolling Mills}

\section{Rolling Mills (2)}

- Loewy 4 high design

- One mill has been retrofitted with direct drive 500 hp motor

- $48^{\prime \prime}$ diameter backup rolls, $12^{\prime \prime}$ work rolls

- Maximum sheet width: $40^{\prime \prime}$

- Maximum rolled sheet length: 25 feet

- Power driven table on both ends

- Integral design with shear at product end of mill

- Preheat oven for heating product on "A" mill line

- Eutectic salt bath for heating product on "B" mill line

- Full length crane systems over each mill table

- 5,000,000 pound separating force

- Recently used to roll 3" stainless steel plate into sheet approximately $0.75^{\prime \prime}$ thick 

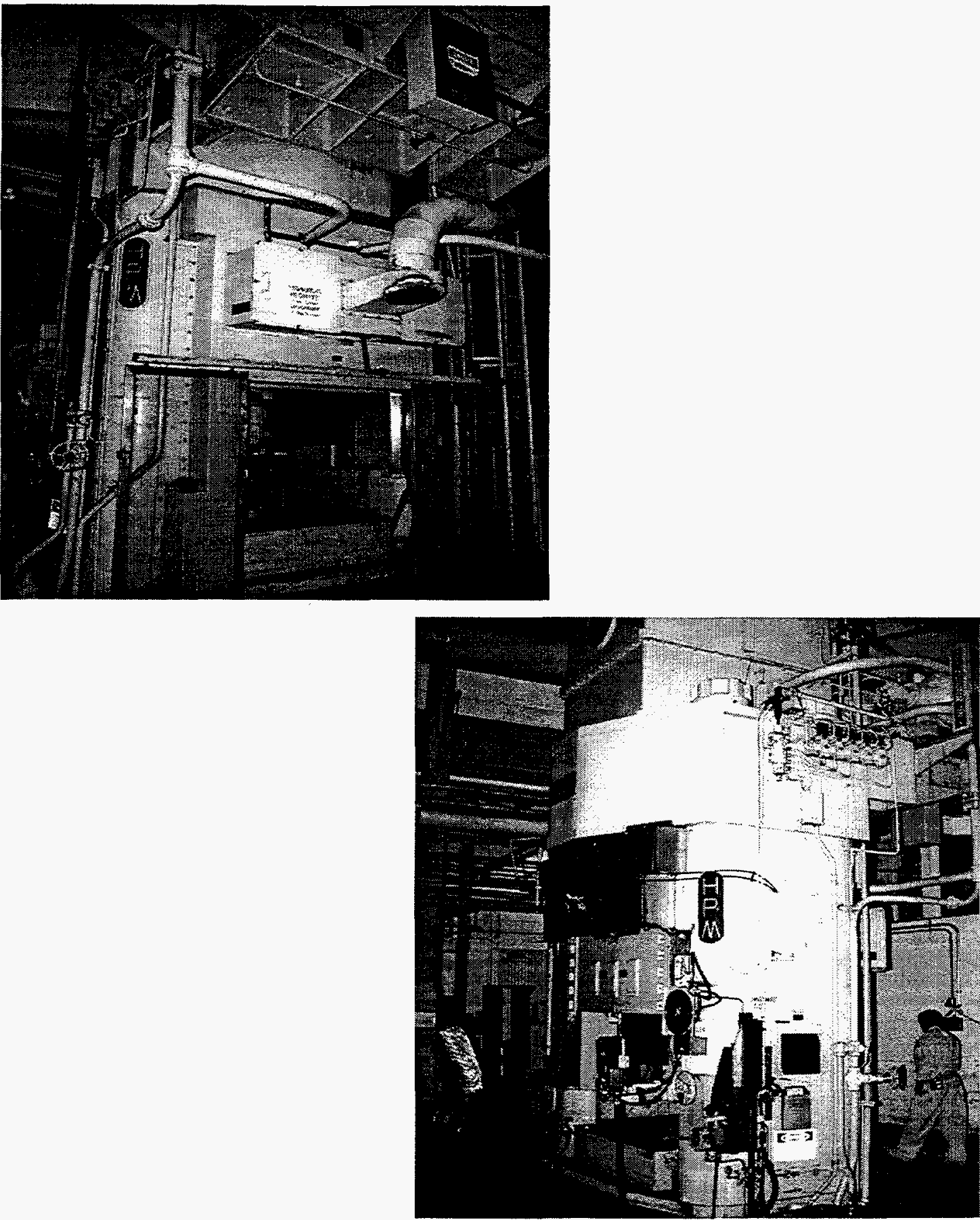

Photos 5 and 6. Large Hydraulic Presses

\section{Hydraulic Presses (2)}

- Hydraulic Press Manufacture (HPM) design

- 2000 ton capacity with 500 ton booster

- Normally used for Marforming (28" rubber die)

- Can be converted to metal punch and die configuration

- 5' x 5' bed, 38" stroke

- Recently used to back extrude stainless 6" steel blanks, 1700 tons pressure 


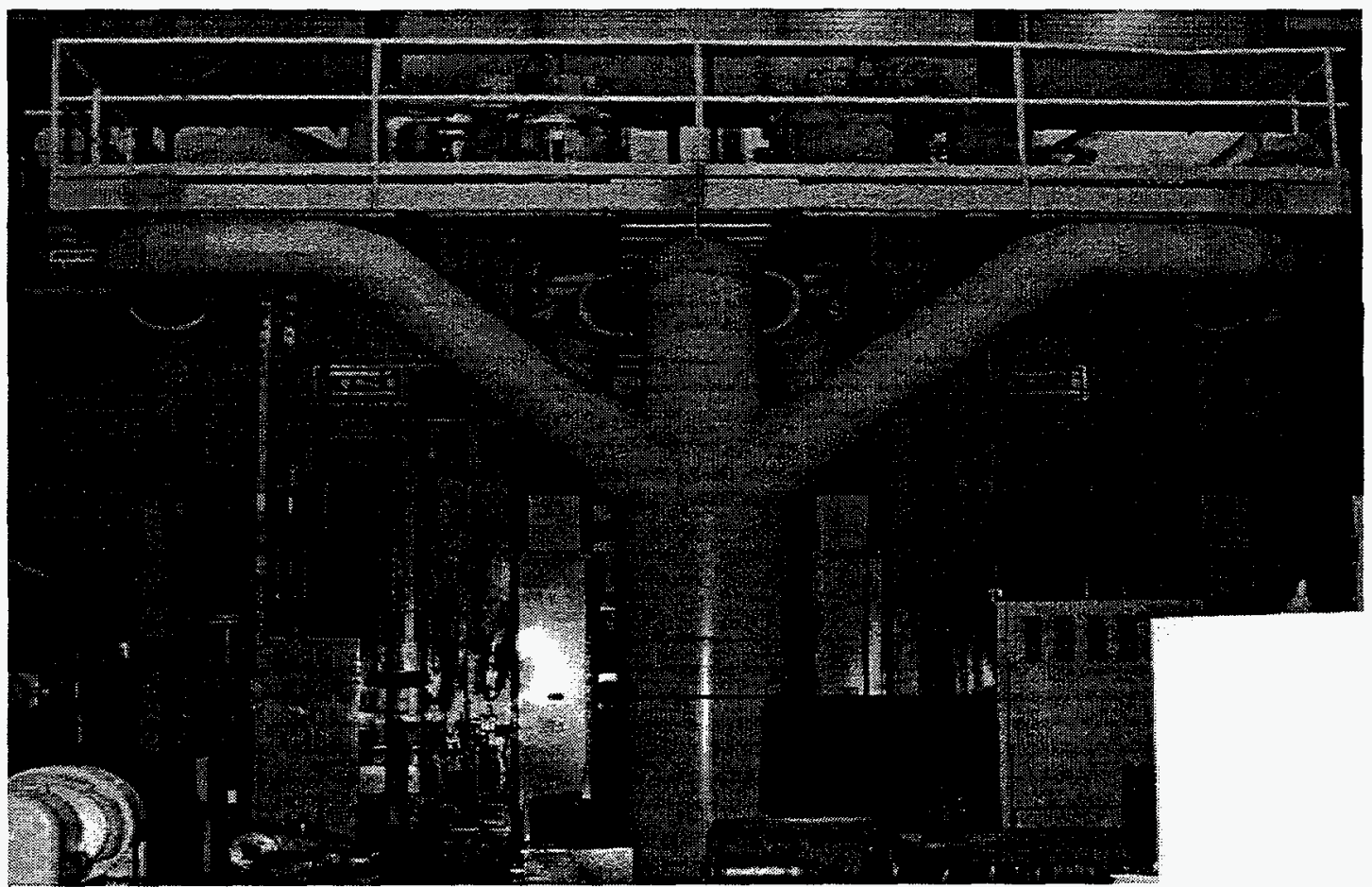

Photo 7. USI Clearing Press

Hydraulic Presses (2)

- USI Clearing design

- $150-300$ ton capacity

- Single / Double action

- 5' x 5' bed, 64" stroke

\section{Hydraulic Press}

- Erie press design

- 300 ton capacity

- 5' x 5' bed, 48" stroke

- Recently used for size reduction (crushing) operations of light gauge steel

\section{Hydraulic Press}

- HydroForm design

- 15,000 psi capacity

- $12^{\prime \prime}$ maximum blank size, 7 draw depth 


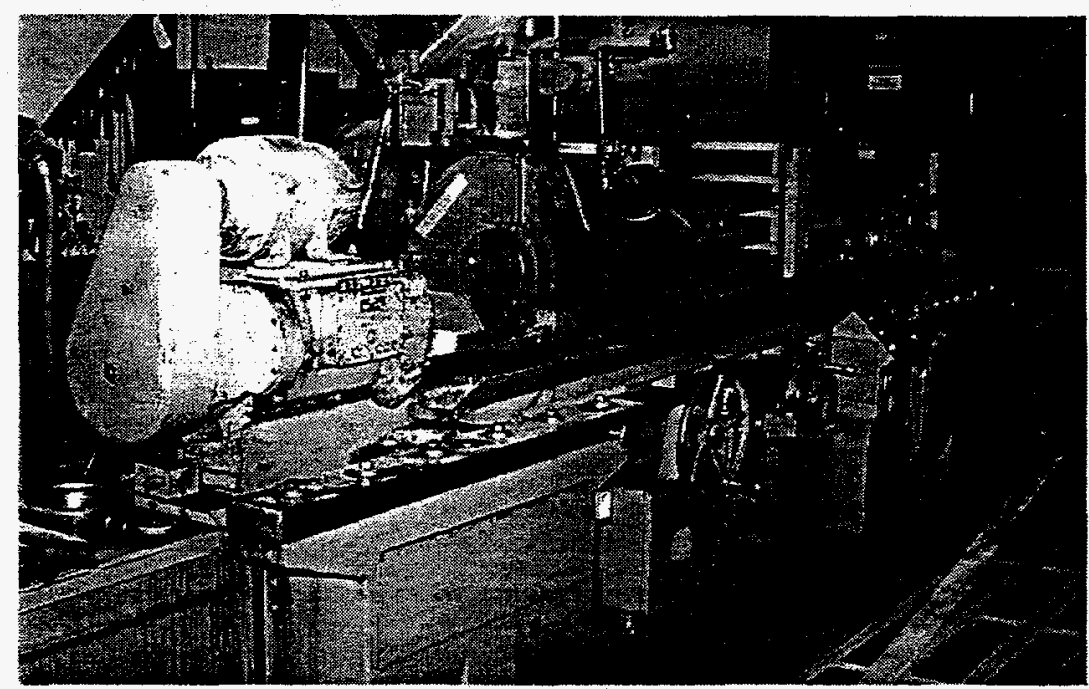

Photo 8. Roll Grinder

\section{Roll Grinder}

- Cincinnati design

- Setup for grinding rolling mill work rolls

- Bed length: 8', 20" maximum diameter

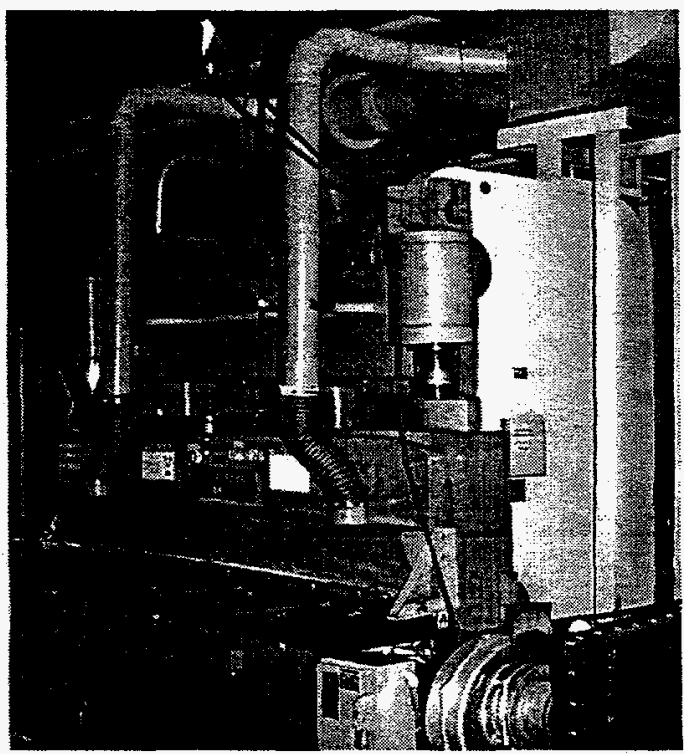

Photo 9. Shear

Shears (3)

- Capacities: $1^{\prime \prime}$ mild steel, 5' bed; 5/8" mild steel, 90" bed; 1/2" mild steel, 48" bed

- All shears recently have been used in operational testing by shearing various thickness of stainless steel 


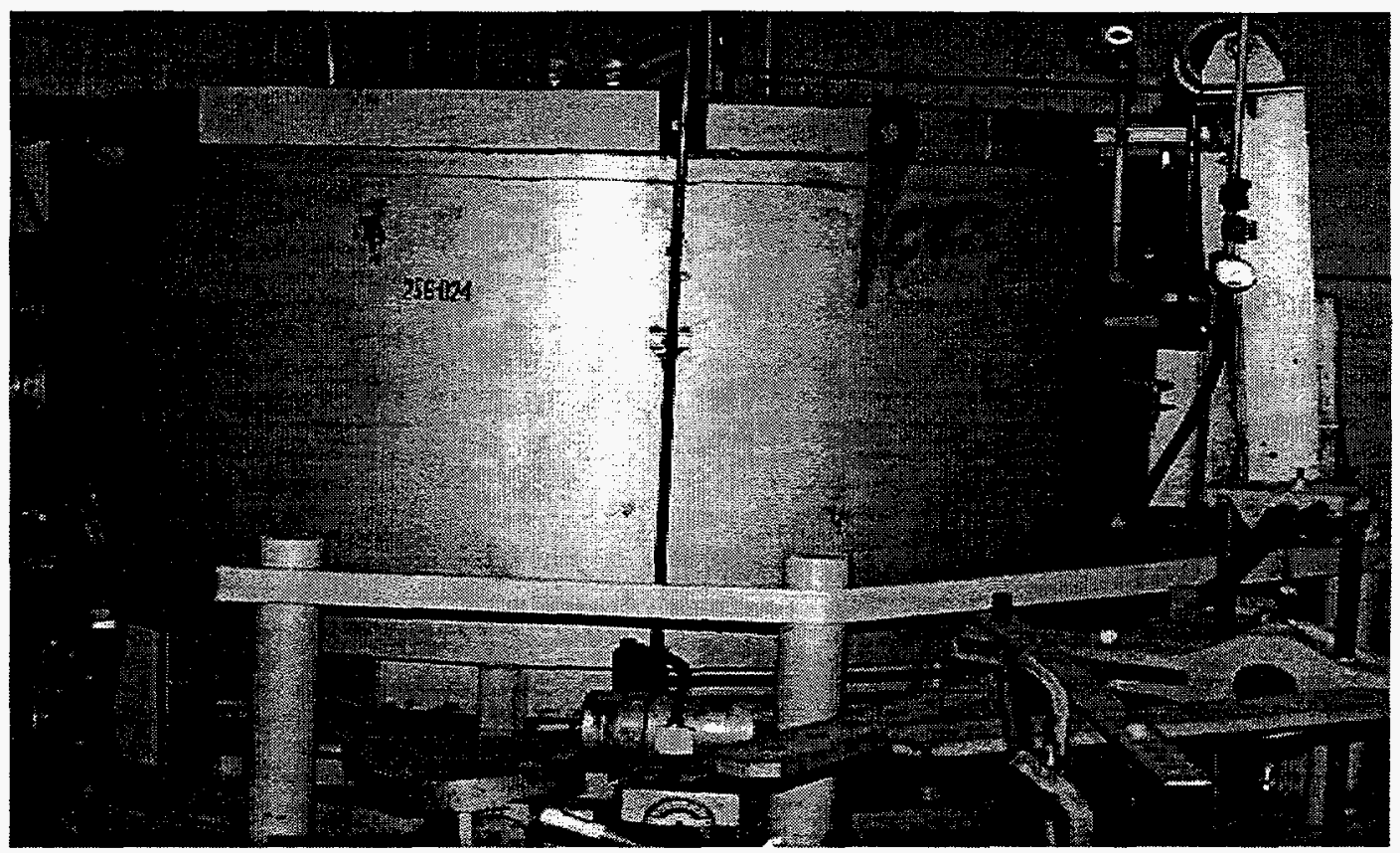

Photo 10. Rotary Furnace

\section{Furnace}

- Lindberg rotary design

- Two zone control

- $2350^{\circ} \mathrm{F}$ continuous, $2500^{\circ} \mathrm{F}$ intermittent

- Variable speed hearth

\section{Furnaces (2)}

- Lindberg Inline design, located along rolling mill table

- $471 / 2^{\prime \prime}$ x 100" x 40" heat zones

- $2000^{\circ} \mathrm{F}$ maximum temperature

- Solid state programmable controllers

- Recently used to anneal stainless steel, aluminum; preheat of stainless steel for extruding 


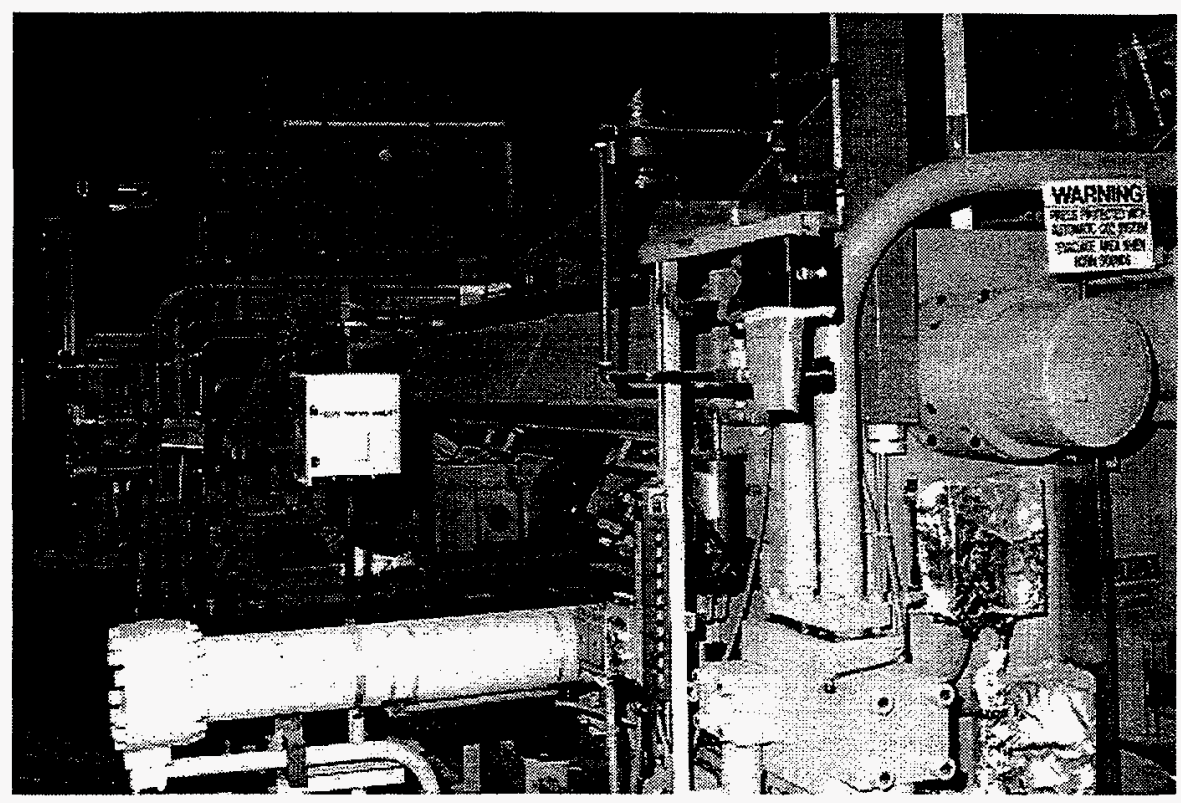

\section{Sutton Extrusion Press}

- Maximum extrusion capacity: 2050 tons

- Main ram operating speed: 0-160" per minute

- Billet container length: 29.4"

- Maximum extrusion length: 34 feet

- Maximum piercing force: 500 tons

- Extrusion modes available: Forward (Direct, Indirect), Backward

\subsection{Site Services}

To support production operations in buildings 865 and 883 , a range of site utilities and services are available, subject to lease negotiations. The charges to be assessed to the successful lessor must be negotiated with DOE. A description of the services available to Building 883 follows. Similar services are available to support building 865 .

Heating, Ventilation. and Air Conditioning (HVAC) System - The Building 883 HVAC serves both human comfort and hazardous material confinement functions. The system that serves the process areas is a once-through system with the inlet air plenums on the north second level. The air is then exhausted through the Building 879 exhaust plenum and then vertically through the two exhaust stacks located on the northeast and southeast corners of the Building 879 roof. Appropriate negative pressure is maintained by control of dampers. Air that enters the inlet plenum is heated by steam or cooled by chillers. The inlet plenums have filters to remove airborne particulates from the outside air. The conditioned air is routed through the process areas via ducts. Some of the air in the process areas is drawn through enclosed confinement boxes near the 
tool heads. This ensures that hazardous vapors and particulates from processing operations are drawn away from the operators. Exhausts from these areas typically have a dedicated HEPA filter

The C Side has a dedicated HVAC system, which uses a HEPA filter to ensure that exhausted air is appropriately conditioned prior to exhaust. This ventilation system is 'motivated by a 250 -horsepower (hp) fan. The office areas have a conventional HVAC system that uses steam heating and evaporative cooling, and is motivated by blowers.

Sanitary and Process Waste Systems - Building 883 is connected to the site sanitary sewer by a 6 -inch underground line. Process wastes are transferred within Building 883 to nine tanks. These tanks were regulated as RCRA Waste Management Units (WMUs) during past operations, but are now considered to be in Interim Status with closure planned prior to occupancy by lessee. Of these nine tanks, seven will be removed, and two will remain.

Compressed Gases - Natural gas from the Site supply enters Building 883 on the south wall at Column Line C. 3 and is only used for HVAC in the building. Compressed air at 110 pounds per square inch (psi) is piped throughout the facility and is provided by a 350-cubic-foot-per-minute (cfm) compressor.

Domestic Cold Water - Domestic cold water is supplied by a 6 -inch underground cast iron pipe. There is an additional 6 -inch line that enters from the north at Room 7. Water is distributed throughout the building. Backflow preventers are used between supplies to the process, fire suppression systems, and domestic services outside the process area. There is an 8-inch line that enters the building at Room 139 and a 6-inch line on the south at Column Line C.9 for fire suppression.

Fire Suppression - The fire suppression system includes automatic sprinkler systems throughout the building, which are supplied by the domestic water system. There are also dry standpipes to the roof, heat detectors, fire extinguishers, and manual pull boxes. The Rocky Flats site currently has 24 hour fire fighting and hazardous material response teams.

Cooling Water Supply $\bullet$ Process cooling water is provided by Cooling Tower 4 (CT-4), which is located on the north exterior of Building 881, south of Building 883 . CT-4 also serves Building 881 . This system is a closed loop system provided by 6 -inch supplies and returns to CT-4. Evaporative cooling is provided by an open-loop water spray over the closed-loop coils. 
Steam System - Steam from the plant supply is provided by 2 -inch underground lines, which enter Building 883 via Room 100. The steam is primarily used for heating, but it is also used for domestic hot water.

Electrical Supply • Building 883 has 5 main switchgear, all with $13.8 \mathrm{kV}$ primary service. Four of these switchgear have 480 volt secondaries, and one has a 2400v secondary. Room 107 is the primary distribution point for power throughout the A Side and B Side. Room 111 is the central point for conversion of alternating current to direct current power using a 500hp motor generator. The 2,400-volt (V) direct current is supplied to the induction furnace and presses in the A Side. 480-volt AC power is distributed throughout the building to power panels, motor control centers, and emergency motor control centers. Standby power is provided from the diesel generator in Building 827.

Vacuum Systems - A building vacuum system is located throughout the building to divert airborne particulates or dusts away from the operators. One system serves the $B$ and $C$ sides and the second system serves side $\mathrm{A}$ and the annex. Material is collected in a bag system in the basement.

There is a health physics vacuum system, located in Room 1 in the basement, that is used to provide building-wide air sampling. The sample filters are routinely collected and analyzed for radioactive particulate.

\section{Other Site Services}

A full range of emergency site services are now available at RFETS, but the lessee may need to put contracts in place with new vendors as these services are privatized.

\subsection{Human Resources}

A critical element of any proposal for commercial utilization of Rocky Flats facilities is the availability of a trained, dedicated work force. During the initial phases of the NCPP, MSC has assembled a work force of skilled technical professionals that should be considered as a resource by companies who might wish to utilize buildings 865 and 883 . Incorporation of the existing work force into any commercial venture would require negotiations with the individual employees.

Shown below is a description of the current workforce, 


\section{Worker Demographics}

The NCPP has developed a highly competent staff of approximately 60 hourly workers with a diverse skill mix. Nearly 90 percent of the workforce are former Rocky Flats workers, who were terminated from the site's contractors due to downsizing through layoff, voluntary separation or early retirement. This workforce possesses unique precision manufacturing skills not normally found in industry.

The median age of male employees is 45 years old; the female employee average age is 37 . There are currently about 50 male and 10 female employees.

\begin{tabular}{|l|c|}
\hline \multicolumn{1}{|c|}{ Skill } & Staff \\
\hline $\begin{array}{l}\text { Semi-skilled (machine operators, support } \\
\text { personnel and light maintenance) }\end{array}$ & 17 \\
\hline Radiation Control Technician (RCT) & 9 \\
\hline $\begin{array}{l}\text { Craft (machinists, welders, pipe fitters, sheet } \\
\text { metal, electricians, etc.) }\end{array}$ & 15 \\
\hline $\begin{array}{l}\text { Waste Technicians (RCRA, TSCA, Radioactive } \\
\text { waste management) }\end{array}$ & 5 \\
\hline $\begin{array}{l}\text { Laboratory Technicians (sample collection and } \\
\text { preparation, radioactive counting instrument } \\
\text { calibration and operations) }\end{array}$ & 2 \\
\hline \begin{tabular}{l} 
Engineering/Technical/Professional \\
\hline
\end{tabular} & 10 \\
\hline
\end{tabular}

Employees have the following training and certifications based on role profile:

- RCRA, TSCA and Radioactive waste characterization, handling and packaging

- 40 hour OSHA (29 CFR 1910)

- Beryllium indoctrination

- CPR 
- Radiological Worker Level II

- RCT Level II

- DOT HM-181 transportation awareness

- State of Colorado certified asbestos technician

- DOE certified trainer/qualification examiner.

\subsection{Environmental}

As noted earlier, a key objective of NCPP Stage II was the environmental remediation of building 865 and 883 . The values to which the Buildings 865 and 883 will be cleaned are shown in Appendix A. Appendix $A$ both describes the minimum clean up values, and the standards to which the clean up will be performed. In most instances, federal standards are dominant.

The values presented in Appendix $A$ are taken from the regulations promulgated by OSHA, and published as 29 Code of Federal Regulations (CFR) Part 1910. Commercial/industrial operations follow the OSHA regulations to maintain workplace conditions so that contaminant levels are less than the personal exposure limits (PELs) stated in the regulations. The PELs are composed of time weighted averages (TWAs), short-term exposure limits (STELs), ceiling concentration limits, and maximum peak concentration limits. STELs, ceiling concentration limits, and maximum peak concentration limits are not promulgated for all substances.

Appendix $B$ lists the past releases and other environmental incidents in these buildings. All of the action items from these releases have been closed out.

The NCPP activities have operated in full compliance with the OSHA regulations, maintaining workplace conditions in a state such that a worker is not exposed to substances in concentrations and forms in excess of the promulgated PELs. In Phases I and Il, the workplace was monitored for all identified contaminants of concern (COCs). In cases where the ambient concentration of a substance in the workplace was found to exceed the action level for that substance, the operator undertook an evaluation to establish if it is safe to temporarily operate at levels exceeding the action level for the substance. Substances were controlled in these areas by employing engineered controls, personal protective equipment, and administrative systems as appropriate to ensure that employees who work in an area where the action limit was exceeded are protected. 
Two contaminants, beryllium and depleted uranium, have been of particular concern, because they are known to be present as a result of past operations. For the NCPP, an As Low As Reasonably Achievable (ALARA) program was established with the goal of operating at contaminant levels lower than the levels permitted by OSHA or, in the case of radiation, established by NRC regulations and DOE orders. It is expected that the leasee will obtain all necessary regulatory approvals, licenses, or permits for his proposed applications.

Even though all exposed contamination will be removed to the standards shown in Appendix A during NCPP Stage II, some areas of the buildings must still be considered to be contaminated. Furthermore, there is the possibility that additional contamination may be exposed if equipment within buildings 865 or 883 is subsequently moved by the leasee. If additional con-tamination is exposed, it will be the responsibility of the leasee to reduce or remove this contamination to acceptable levels. 


\section{Potential Products and Markets}




\section{Section III}

Potential Products and

Markets

The purpose of this section of the Facility Overview is to highlight overall market opportunities and work done to date to identify potential markets for the processes and services of the facility at Rocky Flats which is being offered to private industry for commercial operations. Although some market studies have been conducted, they should in no way limit or influence the range of proposed applications from potentially interested commercial corporations.

\subsection{Commercial Markets}

No comprehensive marketing study or evaluation has been conducted by DOE or the NCPP Stage Il operator related to using this facility for commercial products or services. However, an understanding of the types of operations for which the buildings were designed and used by DOE can be gained from Section 2.4; Buildings, and Section 2.5; Equipment and Capabilities. In summary, the equipment in Building 883 has the capability for rolling and forming operations and the equipment in Building 883 is designed for large metal working operations. The equipment includes; a rolling mill, furnaces, roll grinder, shears, extrusion press, hydraulic press, and machine shop.

Based upon the information in this report, follow-up questions, and planned site tours, companies interested in metal fabrication and related operations should be able to determine the value of this facility for existing and/or potential new business operations.

\subsection{Government Markets}

With respect to potential government markets, two marketing studies have been conducted, and another is in progress, related to the facilities addressed in this report. However, these were targeted studies addressing primarily the markets for products generated from recycling DOE scrap metals. The potential of this facility for addressing government markets is not appreciably different from any competing facility with similar capabilities. The marketability of products produced here will be a function of quality, cost, and the marketing abilities of the facility operator. The award of any potential contract by the Federal government is completely independent of the lease of these buildings. 
A preliminary study to address the potential for operation of these facilities by a commercial corporation was performed by Manufacturing Sciences Corporation (MSC) in 1994. (National Conversion Pilot Project Stage I; Preliminary Market Analysis Report, 24 June 1994, by Manufacturing Sciences Corporation). Potential markets for three DOE scrap metals were examined; (1) radioactive-contaminated scrap metals (RSM), which consists mostly of carbon steel and stainless steel with minor amounts of radioactive contamination, (2) depleted uranium (DU), (3) and beryllium (Be). For each of these metals, the report examined:

- availability of raw material to support recycling activities,

- products that could be made by recycling,

- issues that impact on recycling,

- economic factors that could influence marketability of the products,

- sales potential over the next 5 years as well as in the out years when decommissioning activity will be even greater.

The second study, conducted for DOE by the NASA National Center for Appropriate Technology, (Rocky Flats Recycled Materials Market Study, Performed by NASA Mid-Continent Technology Transfer Center, February 24, 1995) reviewed the conclusions of the MSC market assessment. Copies of both of these studies can be found in the Rocky Flats Reading Room (3645 West $112^{\text {th }}$ Avenue, Westminster, Colorado, 80030, (303) 469-4435) that has been established at Front Range Community College, or at the RFLII office, 5460 Ward Road, Suite 205, Arvada, Colorado 80002, (303) 469-4435. A third study, providing an update on government market opportunities for waste canisters, boxes, shielding, and related products, scheduled for completion in December 1996 , is presently being conducted by Science Applications International Corporation as part of the NCPP.

Based on studies performed to date, there is general agreement that of the three scrap metals evaluated, RSM has the highest potential for producing marketable products for government customers, specifically containers for storing radioactive materials. Even for this use of RSM, questions exist on; (1) Cost competitiveness with containers made from non-radioactive material, (2) Size and timing of markets for containers, (since in some cases, the government will make no commitment at this time on the number required), (3) Ability to meet repository acceptance standards, and (4) The availability of sufficient RSM at Rocky Flats to make containers over a sustained period of time, even if the potential market size were realized. To make the process of building waste containers from RSM viable, RSM might have to be shipped in from other 
DOE facilities. Uncertainties exist on whether shipments of RSM would be acceptable, either across the U.S. and/or to Rocky Flats, and whether sufficient RSM would be available from the other facilities.

The overall amount of RSM in the DOE complex, its composition, and contamination level is also an uncertainty. The present estimate of approximately 155,000 metric tons of RSM in the DOE inventory (see Appendix C) per DOE report EM-0275, "Taking Stock: A Look at the Opportunities and Challenges Posed by Inventories from the Cold War Era", is considerably less than that estimated several years ago and as used in the MSC report, referenced above.

\section{Product Acceptance Criteria for Waste Containers}

In addition, any waste containers must meet the acceptance standards of the government repository into which they will be placed. With respect to high-level radioactive waste (HLW), which is regulated by NRC and will be disposed by DOE, the canister(s) into which the waste are placed are considered to be part of the HLW form. Currently, hazardous waste limitations apply to the HLW form. Waste acceptance requirements preclude the acceptance of a HLW waste form that includes components regulated as hazardous wastes under the Resource Conservation and Recovery Act (RCRA) for disposal in the first geologic repository.

The waste producer is required to determine the presence of any hazardous wastes listed in 40CFR261.31 through 261.33 in the waste or any feed stream proposed for storage or disposal. The waste producer is required to petition EPA and receive an exemption to delist any RCRAlisted component in a waste or feed stream.

The waste producer is required to perform tests as described in 40CFR261.20 through 261.24 to determine if the HLW waste form has hazardous characteristics. Any waste that is shown to have hazardous characteristics must be treated to remove such characteristics.

The waste producer must certify, in the Waste Form Qualification Report, that the HLW waste form is not hazardous, including the absence of any listed components. The methods used to conduct characteristic testing must be described in the Waste Form Compliance Plan, and the results documented in the Waste Form Qualification Report. 
The canister is also subject to specific configuration, weight, labeling, testing, and handling feature requirements. Thus, to compete for this business, a vendor would have to assure that its products met all performance criteria, and did not contain any hazardous substances prohibited by current DOE waste acceptance criteria.

A project to demonstrate the applicability of using the equipment available under this RFI, for constructing radioactive waste storage containers using RSM, is being conducted as part of the NCPP. This project, termed "Process Verification", is described in the following section.

\subsection{Process Verification Support}

Process verification activities performed in Buildings 883 and 865 have included the fabrication of two sizes of Transuranic Waste Containers. The components for the containers were made of stainless steel that was rolled using one of the rolling mills in Building 883. Blanks were then press formed and back extruded using the 2000 ton HPM presses. After pressing, components were transferred to Building 865 where spin forming and annealing was performed. Finally, after several machining steps using both lathes and mills, the components were welded using a GTA welder, followed by leak testing.

These process verification activities operationally tested two furnaces, a rolling mill, both 2000 presses, the spinning machine, a GTA welder, vacuum leak detector and numerous machine tools. Twenty four transuranic waste containers were fabricated during the process verification, and have been delivered to Sandia National Laboratory for testing. 




spגepuets

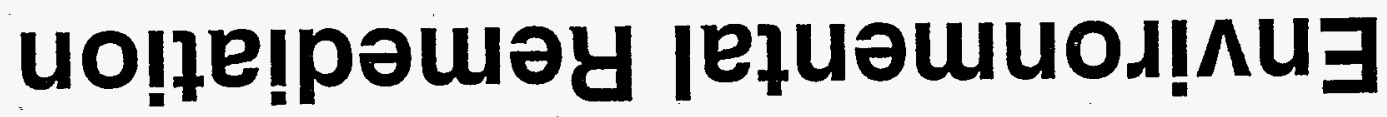
$: \forall$ X!puədd $\forall$ 


SUBSTANCE SUREACE SOURCE AIR LIMITS SOURCE REMARKS

Metals

\begin{tabular}{|c|c|c|c|c|c|}
\hline $\begin{array}{l}\text { Aluminum } \\
\text { (as } \mathrm{Al} \\
\text { metal) }\end{array}$ & * & & $\begin{array}{l}\text { Qccupational Worker } \\
15 \mathrm{mg} / \mathrm{m}^{3} \text { TWA (total } \\
\text { dust) } \\
5 \mathrm{mg} / \mathrm{m}^{3} \text { TWA } \\
\text { (respirable fraction) }\end{array}$ & 29CFR1910.1000 & \\
\hline $\begin{array}{l}\text { Arsenic } \\
\text { (as As) }\end{array}$ & * & & $\begin{array}{l}\text { Occupational Worker } \\
0.5 \mathrm{mg} / \mathrm{m}^{3} \text { TWA } \\
\text { (Organic Compounds) } \\
10 \mu \mathrm{g} / \mathrm{m}^{3} \text { TWA } \\
\text { (Inorganic } \\
\text { Compounds) }\end{array}$ & $\begin{array}{l}\text { 29CFR1910.1000 } \\
\text { 29CFR1910.1018 }\end{array}$ & $\begin{array}{l}\text { Inorganic } \\
\text { Arsenic is a } \\
\text { Confirmed } \\
\text { Carcinogen. }\end{array}$ \\
\hline $\begin{array}{l}\text { Barium (as } \\
\mathrm{Ba} \text { ) }\end{array}$ & * & & $\begin{array}{l}\frac{\text { Occupational Worker }}{0.5 \mathrm{mg} / \mathrm{m}^{3} \mathrm{TWA}} \\
\text { (soluble) }\end{array}$ & 29CFR1910.1000 & \\
\hline $\begin{array}{l}\text { Beryllium } \\
\text { and } \\
\text { Beryllium } \\
\text { Compound } \\
\text { s } \\
\text { (as Be) }\end{array}$ & $\begin{array}{l}\text { Qccupational } \\
\text { Worker } \\
25 \mu \mathrm{g} / \mathrm{ft}^{2}\end{array}$ & HSP 13.04 & $\begin{array}{l}\text { Occupational Worker } \\
2 \mu \mathrm{g} / \mathrm{m}^{3} \text { TWA } \\
5 \mu \mathrm{g} / \mathrm{m}^{3} \\
\text { (Acceptable Ceiling } \\
\text { Conc.) } \\
25 \mu \mathrm{g} / \mathrm{m}^{3} \text { for } 30 \mathrm{~min} \text {. } \\
\text { (Acceptable } \\
\text { Max.Peak) } \\
\\
2 \mu \mathrm{g} / \mathrm{m}^{3} \text { TWA } \\
0.5 \mu \mathrm{g} / \mathrm{m}^{3} \text { (action level) }\end{array}$ & $\begin{array}{l}\text { 29CFR1910.1000 } \\
\text { HSP } 13.03 \\
\text { HSP } 13.04\end{array}$ & $\begin{array}{l}\text { Current Plant } \\
\text { standard, not } \\
\text { codified. }\end{array}$ \\
\hline $\begin{array}{l}\text { Cadmium } \\
\text { (as Cd) }\end{array}$ & * & & $\begin{array}{l}\text { Occupational Worker } \\
0.1 \mathrm{mg} / \mathrm{m}^{3} \text { TWA (fume) } \\
0.3 \mathrm{mg} / \mathrm{m}^{3} \text { Ceiling } \\
\text { (fume) } \\
0.2 \mathrm{mg} / \mathrm{m}^{3} \text { TWA (dust) } \\
0.6 \mathrm{mg} / \mathrm{m}^{3} \text { Ceiling (dust) }\end{array}$ & 29CFR1910.1000 & \\
\hline Chromium & * & & $\begin{array}{l}\text { Occupational Worker } \\
0.1 \mathrm{mg} / \mathrm{m}^{3} \text { Ceiling (as } \\
\mathrm{CrO}_{3} \text { ) } \\
0.5 \mathrm{mg} / \mathrm{m}^{3} \mathrm{TWA} \text { (as } \mathrm{Cr} \\
\mathrm{cmpnd} \text { ) } \\
1 \mathrm{mg} / \mathrm{m}^{3} \mathrm{TWA} \text { (as } \mathrm{Cr} \text { as } \\
\text { metal) }\end{array}$ & 29CFR1910.1000 & $\begin{array}{l}\text { Hexavalent } \\
\text { Chromium is } \\
\text { a Confirmed } \\
\text { Carcinogen. }\end{array}$ \\
\hline $\begin{array}{l}\text { Lead (as } \\
\mathrm{Pb} \text { ) }\end{array}$ & * & & $\begin{array}{l}\text { Qccupational Worker } \\
30 \mu \mathrm{g} / \mathrm{m}^{3} \text { Action Level } \\
50 \mu \mathrm{g} / \mathrm{m}^{3} \text { TWA }\end{array}$ & 29CFR1910.1025 & \\
\hline
\end{tabular}

- In the event that this $\mathrm{COC}$ is identified as being present, the surface will be cleaned to a reasonably achievable level according to the ALARA principle. 


SUBSTANCE $\frac{\text { SURFACE }}{\text { LIMITS }} \quad$ SOURCE SOIR LIMITS $\quad$ SOURCE

\begin{tabular}{|c|c|c|c|c|c|}
\hline $\begin{array}{l}\text { Lithium } \\
\text { (as a } \\
\text { hydride) }\end{array}$ & ${ }^{*}$ & & $\frac{\text { Occupational Worker }}{0.025 \mathrm{mg} / \mathrm{m}^{3} \mathrm{TWA}}$ & 29CFR1910.1000 & \\
\hline $\begin{array}{l}\text { Silver (as } \\
\mathrm{Ag} \text { ) }\end{array}$ & * & & $\begin{array}{l}\text { Occupational Worker } \\
0.01 \mathrm{mg} / \mathrm{m}^{3} \mathrm{TWA} \\
\text { (metal \& soluble } \\
\text { compounds) }\end{array}$ & 29CFR1910.1000 & \\
\hline $\begin{array}{l}\text { Niobium } \\
\text { (as Se) } \\
\text { (See } \\
\text { Remarks) } \\
\end{array}$ & * & & $\begin{array}{l}\text { Occupational Worker } \\
0.2 \mathrm{mg} / \mathrm{m}^{3} \mathrm{TWA} \\
\text { (compounds) }\end{array}$ & 29CFR1910.1000 & $\begin{array}{l}\text { Selenium } \\
\text { values used in } \\
\text { place of } \\
\text { Niobium. }\end{array}$ \\
\hline $\begin{array}{l}\text { Uranium } \\
(\mathrm{U}- \\
235 \& 238) \\
(\alpha)\end{array}$ & $\begin{array}{l}\text { Qccupational } \\
\text { Worker } \\
1,000 \\
\text { dpm/100 cm } 2 \\
\text { (removable) } \\
5,000 \\
\text { dpm/100 cm } 2 \\
\text { (fixed plus } \\
\\
\text { removable) } \\
\\
1,000 \\
\text { dpm/100 cm } 2 \\
\text { (removable) } \\
5,000 \\
\text { dpm/100 cm } 2 \\
\text { (average) } \\
15,000 \\
\text { dpm/100 cm } 2 \\
\text { (max.) }\end{array}$ & $\begin{array}{l}\text { DOE } 5480.11 \\
\text { Reg. Guide } \\
1.86\end{array}$ & $\begin{array}{c}\text { Occupational Worker } \\
0.05 \mathrm{mg} / \mathrm{m}^{3} \mathrm{TWA} \text { (as } \mathrm{U} \text { ) } \\
\text { (soluble } \\
\text { compounds) } \\
0.05 \mathrm{mg} / \mathrm{m}^{3} \mathrm{TWA} \text { (as } \mathrm{U} \text { ) } \\
\text { (insoluble } \\
\text { compounds) } \\
0.6 \mathrm{mg} / \mathrm{m} 3 \mathrm{STEL} \text { (as } \mathrm{U} \text { ) } \\
\quad \text { (insoluble } \\
\text { compounds) } \\
\\
\mathrm{U}^{235} \text { and } \mathrm{U}^{238} \\
6 \times 10^{-10} \mu \mathrm{Ci} / \mathrm{ml} \text { (Days) } \\
3 \times 10^{-10} \mu \mathrm{Ci} / \mathrm{ml} \text { (Weeks) } \\
2 \times 10^{-11} \mu \mathrm{Ci} / \mathrm{ml} \text { (Years) } \\
\\
\mathrm{U}^{235} \text { and } \mathrm{U}^{2} 238 \text { (DACs) } \\
6 \times 10^{-10} \mu \mathrm{Ci} / \mathrm{ml} \text { (Days) } \\
3 \times 10^{-10} \mu \mathrm{Ci} / \mathrm{ml} \text { (Weeks) } \\
2 \times 10^{-11} \mu \mathrm{Ci} / \mathrm{ml} \text { (Years) }\end{array}$ & $\begin{array}{l}29 \text { CFR } 1910.1000 \\
\\
10 \text { CFR835, } \\
\text { Appendix A } \\
\text { DOE 5480.11 } \\
\text { 6CCR 1007-1, Pt. } \\
4 \\
\text { Appendix B }\end{array}$ & \\
\hline
\end{tabular}

- In the event that this COC is identified as being present, the surface will be cleaned to a reasonably achievable level according to the ALARA principle. 


SUBSTANCE SUREACE $\frac{\text { SOURCE }}{\text { LIMITS }}$

\begin{tabular}{|c|c|c|c|c|}
\hline $\begin{array}{l}\text { Alpha } \\
\text { (Trans- } \\
\text { uranics) } \\
(\alpha)\end{array}$ & $\begin{array}{l}\frac{\text { Occupational }}{\text { Worker }} \\
20 \mathrm{dpm} / 100 \\
\mathrm{~cm}^{2} \\
\text { (removable) } \\
300 \mathrm{dpm} / 100 \\
\mathrm{~cm}^{2} \text { (fixed } \\
\text { plus } \\
\text { removable) } \\
20 \text { dpm/100 } \\
\mathrm{cm}^{2} \\
\text { (removable) } \\
100 \text { dpm/100 } \\
\mathrm{cm}^{2} \text { (average) } \\
300 \text { dpm } / 100 \\
\mathrm{~cm}^{2} \text { (max.) }\end{array}$ & $\begin{array}{l}\text { DOE } 5480.11 \\
\text { Reg. Guide } \\
1.86\end{array}$ & $\begin{array}{l}\text { Based upon the values } \\
\text { for the individual Alpha } \\
\text { emitting elements, i.e., } \\
\text { Transuranics, } \mathrm{Ra}^{226} \text { and } \\
\mathrm{Ra}^{228} \text {. }\end{array}$ & \\
\hline $\begin{array}{l}\text { Beta- } \\
\text { Gamma } \\
(w / e x \\
\left.\mathrm{Sr}^{90}\right) \\
(\beta-\gamma)\end{array}$ & $\begin{array}{l}\frac{\text { Occupational }}{\text { Worker }} \\
1,000 \\
\text { dpm/100 cm } \\
\text { (removable) } \\
5,000 \\
\text { dpm/100 cm } 2 \\
\text { (fixed plus } \\
\text { removable) } \\
\\
1,000 \\
\text { dpm/100 cm } 2 \\
\text { (removable) } \\
5,000 \\
\text { dpm/100 cm } 2 \\
\text { (average) } \\
15,000 \\
\text { dpm/100 cm } 2 \\
\text { (max.) }\end{array}$ & $\begin{array}{l}\text { DOE 5480.11 } \\
\\
\text { Reg. Guide } \\
1.86\end{array}$ & $\begin{array}{l}\text { Based upon the values } \\
\text { for the individual Alpha } \\
\text { emitting elements, i.e., } \\
\text { Th234. }\end{array}$ & $\begin{array}{l}\mathrm{Sr}^{90} \text { has the } \\
\text { same surface } \\
\text { contamination } \\
\text { values as } \\
\text { Radon. }\end{array}$ \\
\hline
\end{tabular}

- In the event that this $C O C$ is identified as being present, the surface will be cleaned to a reasonably achievable level according to the ALARA principle. 


SUBSTANCE $\frac{\text { SURFACE }}{\text { LIMITS }} \quad$ SOURCE

\begin{tabular}{|c|c|c|c|c|}
\hline $\begin{array}{l}\text { Radon } \\
\left(\mathrm{Rn}^{220},\right. \\
\left.\mathrm{Rn}^{222}\right) \\
\text { and its } \\
\text { daughter } \\
\text { products }\end{array}$ & $\begin{array}{l}\frac{\text { Qccupational }}{\text { Worker }} \\
200 \text { dpm/100 } \\
\mathrm{cm}^{2} \\
\text { (removable) } \\
1,000 \\
\text { dpm/100 cm } 2 \\
\text { (fixed plus } \\
\text { removable) } \\
\\
200 \text { dpm } / 100 \\
\mathrm{~cm}^{2} \\
\text { (removable) } \\
1,000 \\
\text { dpm/100 cm } 2 \\
\text { (average) } \\
3,000 \\
\text { dpm/100 cm } 2 \\
\text { (max.) }\end{array}$ & $\begin{array}{l}\text { DOE } 5480.11 \\
\\
\text { Reg. Guide } \\
1.86\end{array}$ & $\begin{array}{l}\text { Qccupational Worker } \\
\mathrm{Rn}^{220} \text { (Immersion DAC) } \\
8 \times 10^{-9} \mu \mathrm{Ci} / \mathrm{ml} \text { or } 1.0 \\
\mathrm{WL} \text { (annual average } \\
\text { including background) } \\
\\
\\
\mathrm{Rn}^{222} \text { (Immersion DAC) } \\
3 \times 10^{-8} \mu \mathrm{Ci} / \mathrm{ml} \text { or } 0.33 \\
\mathrm{WL} \text { (annual average } \\
\text { including background) }\end{array}$ & $\begin{array}{l}\text { 10CFR835, } \\
\text { Appendices A\&C } \\
\text { DOE 5480.11 } \\
\\
\text { 10CFR835, } \\
\text { Appendices A\&C } \\
\text { DOE 5480.11 }\end{array}$ \\
\hline \multicolumn{5}{|c|}{ Salts } \\
\hline $\begin{array}{l}\text { Cyanides } \\
\text { (as } \mathrm{CN} \text { ) }\end{array}$ & * & & $5 \frac{\text { Qccupational Worker }}{5 \mathrm{mg} / \mathrm{m}^{3} \text { TWA }}$ & 29CFR1910.1000 \\
\hline $\begin{array}{l}\text { Sodium } \\
\text { Cyanide }\end{array}$ & * & & $\begin{array}{l}\text { Qccupational Worker } \\
5 \mathrm{mg} / \mathrm{m}^{3} \text { TWA (as CN } \\
\text { only) }\end{array}$ & 29CFR 1910.1000 \\
\hline $\begin{array}{l}\text { Barium } \\
\text { Cyanide }\end{array}$ & * & & $\begin{array}{l}\text { Qccupational Worker } \\
0.5 \mathrm{mg} / \mathrm{m}^{3} \mathrm{TWA} \\
\text { (as Ba soluble } \\
\text { compounds) } \\
5 \mathrm{mg} / \mathrm{m}^{3} \text { TWA (as } \mathrm{CN} \text { ) }\end{array}$ & 29CFR 1910.1000 \\
\hline $\begin{array}{l}\text { Cadmium } \\
\text { Cyanide }\end{array}$ & * & & $\begin{array}{l}\text { Occupational Worker } \\
0.1 \mathrm{mg} / \mathrm{m}^{3} \mathrm{TWA} \text { (as Cd } \\
\text { fume) } \\
0.2 \mathrm{mg} / \mathrm{m}^{3} \text { TWA (as Cd } \\
\text { dust) } \\
0.6 \mathrm{mg} / \mathrm{m}^{3} \text { Ceiling (as Cd } \\
\text { dust) } \\
0.3 \mathrm{mg} / \mathrm{m}^{3} \text { Ceiling (as } \\
\text { Cd fume) } \\
5 \mathrm{mg} / \mathrm{m}^{3} \text { TWA (as CN) } \\
\end{array}$ & 29CFR 1910.1000 \\
\hline
\end{tabular}

- In the event that this COC is identified as being present, the surface will be cleaned to a reasonably achievable level according to the ALARA principle. 


SUBSTANCE $\frac{\text { SUREACE }}{\text { LIMITS }} \quad$ SOURCE AIRLIMITS $\quad$ SOURCE REMARKS

\begin{tabular}{|c|c|c|c|c|}
\hline $\begin{array}{l}\text { Barium } \\
\text { Chloride }\end{array}$ & * & $\begin{array}{l}\text { Qccupational Worker } \\
0.5 \mathrm{mg} / \mathrm{m}^{3} \mathrm{TWA} \\
\text { (as Ba soluble } \\
\text { compound) }\end{array}$ & 29CFR1910.1000 & \\
\hline \multicolumn{5}{|c|}{ Solvents, Oils } \\
\hline $\begin{array}{l}\text { Trichloro- } \\
\text { ethylene }\end{array}$ & * & $\begin{array}{l}\text { Qccupational Worker } \\
100 \text { ppm TWA } \\
200 \text { ppm Ceiling }\end{array}$ & 29CFR1910.1000 & \\
\hline $\begin{array}{l}\text { Chloro- } \\
\text { form } \\
\text { (Trichloro- } \\
\text { methane) }\end{array}$ & $*$ & $\begin{array}{l}\text { Occupational Worker } \\
2 \text { ppm TWA } \\
9.78 \mathrm{mg} / \mathrm{m}^{3} \text { TWA }\end{array}$ & 29CFR1910.1000 & $\begin{array}{l}\text { Suspected } \\
\text { Carcinogen }\end{array}$ \\
\hline $\begin{array}{l}\text { Methyl } \\
\text { Chloro- } \\
\text { form } \\
(1,1,1- \\
\text { Trichloro- } \\
\text { ethane) }\end{array}$ & * & $\begin{array}{l}\text { Occupational Worker } \\
350 \mathrm{ppm} \text { TWA } \\
1900 \mathrm{mg} / \mathrm{m}^{3} \text { TWA }\end{array}$ & 29CFR1910.1000 & \\
\hline $\begin{array}{l}1,1,2- \\
\text { Trichloro- } \\
\text { ethane }\end{array}$ & * & $\begin{array}{l}\text { Occupational Worker } \\
10 \mathrm{ppm} \mathrm{TWA} \\
45 \mathrm{mg} / \mathrm{m}^{3} \text { TWA }\end{array}$ & 29CFR1910.1000 & $\begin{array}{l}\text { Protection } \\
\text { from skin } \\
\text { contact } \\
\text { required. }\end{array}$ \\
\hline $\begin{array}{l}\text { Carbon } \\
\text { Tetra- } \\
\text { chloride } \\
\text { (Tetra- } \\
\text { chloro- } \\
\text { methane) }\end{array}$ & * & $\begin{array}{l}\text { Qccupational Worker } \\
2 \text { ppm STEL (over } 60 \\
\text { min) } \\
10 \text { ppm PEL } \\
25 \text { ppm Ceiling } \\
200 \text { ppm (5 min max) }\end{array}$ & 29CFR1910.1000 & $\begin{array}{l}\text { Suspected } \\
\text { Carcinogen }\end{array}$ \\
\hline $\begin{array}{l}\text { Ethylene } \\
\text { Dichloride }\end{array}$ & * & $\begin{array}{l}\text { Qccupational Worker } \\
1 \text { ppm TWA } \\
2 \text { ppm STEL }\end{array}$ & $\begin{array}{l}\text { NIOSH Pocket } \\
\text { Guide to Chemical } \\
\text { Hazards USDHHS }\end{array}$ & \\
\hline Acetone & $*$ & $\begin{array}{l}\text { Occupational Worker } \\
250 \text { ppm TWA }\end{array}$ & $\begin{array}{l}\text { NIOSH Pocket } \\
\text { Guide to Chemical } \\
\text { Hazards USDHHS }\end{array}$ & \\
\hline
\end{tabular}

- In the event that this COC is identified as being present, the surface will be cleaned to a reasonably achievable level according to the ALARA principle. 


SUBSTANCE SURFACE SOURCE SIR LIMITS

\begin{tabular}{|c|c|c|c|c|}
\hline Benzene & * & $\begin{array}{l}\text { Occupational Worker } \\
1 \mathrm{ppm} \text { TWA } \\
5 \mathrm{ppm} \text { in } 15 \mathrm{~min} \text {. max. }\end{array}$ & 29CFR1910.1028 & $\begin{array}{l}\text { Confirmed } \\
\text { Carcinogen }\end{array}$ \\
\hline Toluene & * & $\begin{array}{l}\text { Qccupational Worker } \\
100 \text { ppm TWA } \\
150 \text { ppm STEL }\end{array}$ & $\begin{array}{l}\text { NIOSH Pocket } \\
\text { Guide to Chemical } \\
\text { Hazards USDHHS }\end{array}$ & \\
\hline $\begin{array}{l}\text { Methyl } \\
\text { Ethyl } \\
\text { Ketone } \\
\text { Peroxide } \\
\text { (MEKP) } \\
\end{array}$ & * & $\begin{array}{l}\text { Qccupational Worker } \\
0.2 \mathrm{ppm} \text { Ceiling }\end{array}$ & $\begin{array}{l}\text { NIOSH Pocket } \\
\text { Guide to Chemical } \\
\text { Hazards USDHHS }\end{array}$ & \\
\hline $\begin{array}{l}\text { Methylene } \\
\text { Chloride } \\
\text { (Dichloro } \\
\text { methane) }\end{array}$ & $*$ & $\begin{array}{l}\text { Occupational Worker } \\
500 \mathrm{ppm} \text { TWA } \\
\text { 1,000 ppm Acceptable } \\
\text { Ceiling } \\
2,000 \mathrm{ppm} 5 \mathrm{~min} \text { in any } 2 \\
\text { hrs (Acceptable } \\
\text { Maximum Peak) }\end{array}$ & 29CFR1910.1000 & $\begin{array}{l}\text { Suspected } \\
\text { Carcinogen }\end{array}$ \\
\hline $\begin{array}{l}\text { Xylenes } \\
\text { (m-, o- \& } \\
\text { p- } \\
\text { isomers) }\end{array}$ & $*$ & $\begin{array}{l}\text { Occupationa! Worker } \\
100 \text { ppm TWA } \\
150 \text { ppm STEL }\end{array}$ & $\begin{array}{l}\text { 29CFR1910.1000 } \\
\text { NIOSH Pocket } \\
\text { Guide to Chemical } \\
\text { Hazards USDHHS }\end{array}$ & \\
\hline $\begin{array}{l}\text { 2-Butan- } \\
\text { one } \\
\text { [Methy] } \\
\text { Ethyl } \\
\text { Ketone } \\
\text { (MEK)] }\end{array}$ & 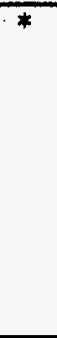 & $\begin{array}{l}\text { Occupational Worker } \\
200 \text { ppm TWA } \\
300 \text { ppm STEL }\end{array}$ & $\begin{array}{l}\text { NIOSH Pocket } \\
\text { Guide to Chemical } \\
\text { Hazards USDHHS }\end{array}$ & \\
\hline $\begin{array}{l}\text { Perchloro- } \\
\text { ethylene } \\
\text { (Tetra- } \\
\text { chloro- } \\
\text { ethylene) }\end{array}$ & * & $\begin{array}{l}\text { Occupational Worker } \\
100 \mathrm{ppm} \text { TWA } \\
200 \mathrm{ppm} \text { Ceiling } \\
300 \mathrm{ppm}(5 \mathrm{~min} \max \\
\text { peak in any } 3 \mathrm{hrs} \text { ) }\end{array}$ & 29CFR1910.1000 & \\
\hline $\begin{array}{l}\text { Ethylene } \\
\text { oxide } \\
\text { (Oxirane) }\end{array}$ & $*$ & $\begin{array}{c}\text { Occupational Worker } \\
1 \mathrm{ppm} \text { TWA (Permissible } \\
\text { Exposure Limit) } \\
5 \mathrm{ppm} \text { in } 15 \mathrm{~min} \text {. STEL } \\
\text { (Excursion Limit) }\end{array}$ & 29CFR1910.1047 & $\begin{array}{l}\text { Confirmed } \\
\text { Carcinogen }\end{array}$ \\
\hline
\end{tabular}

- In the event that this $\mathrm{COC}$ is identified as being present, the surface will be cleaned to a reasonably achievable level according to the ALARA principle. 
SUBSTANCE SUREACE $\frac{\text { SOURCE }}{\text { LIMITS }}$ SOURLIMITS

\begin{tabular}{|c|c|c|c|c|}
\hline $\begin{array}{l}\text { Di-sec } \\
\text { octyl } \\
\text { phthalate } \\
\text { (Di-2- } \\
\text { ethylhexyl } \\
\text { - } \\
\text { phthalate) }\end{array}$ & $*$ & $\begin{array}{l}\text { Qccupational Worker } \\
5 \mathrm{mg} / \mathrm{m}^{3} \mathrm{TWA} \\
10 \mathrm{mg} / \mathrm{m}^{3} \text { STEL }\end{array}$ & $\begin{array}{l}\text { 29CFR1910.1000 } \\
\text { NIOSH Pocket } \\
\text { Guide to Chemical } \\
\text { Hazards USDHHS }\end{array}$ & \\
\hline $\begin{array}{l}\text { Ethylene } \\
\text { Glycol }\end{array}$ & * & $\begin{array}{l}\text { Qccupational Worker } \\
50 \text { ppm Ceiling }\end{array}$ & $\begin{array}{l}\text { NIOSH Pocket } \\
\text { Guide to Chemical } \\
\text { Hazards USDHHS } \\
\text { (Not yet } \\
\text { established) }\end{array}$ & $\begin{array}{l}\text { Suspected } \\
\text { Carcinogen }\end{array}$ \\
\hline Hydrazine & $*$ & $\begin{array}{l}\text { Occupational Worker } \\
1 \mathrm{ppm} \text { TWA } \\
0.03 \text { ppm Ceiling }\end{array}$ & $\begin{array}{l}\text { 29CFR } 1910.1000 \\
\text { NIOSH Pocket } \\
\text { Guide to Chemical } \\
\text { Hazards USDHHS }\end{array}$ & $\begin{array}{l}\text { Suspected } \\
\text { Carcinogen } \\
\text { Protection } \\
\text { from skin } \\
\text { contact } \\
\text { required. }\end{array}$ \\
\hline Benzidine & * & $\begin{array}{l}\text { Occupational Worker } \\
\text { No allowable exposure } \\
\text { limits have been defined. } \\
\text { Exposure shall be } \\
\text { minimized. }\end{array}$ & 29CFR1910.1010 & $\begin{array}{l}\text { Confirmed } \\
\text { Carcinogen }\end{array}$ \\
\hline $\begin{array}{l}\text { Formalde- } \\
\text { hyde }\end{array}$ & * & $\begin{array}{l}\text { Occupational Worker } \\
0.016 \text { ppm TWA } \\
0.1 \text { ppm Ceiling in } 15 \\
\text { min. } \\
0.75 \text { ppm } \\
2 \text { ppm STEL }\end{array}$ & $\begin{array}{l}\text { NIOSH Pocket } \\
\text { Guide to Chemical } \\
\text { Hazards USDHHS } \\
\text { 29CFR1910.1048 }\end{array}$ & $\begin{array}{l}\text { Confirmed } \\
\text { Carcinogen }\end{array}$ \\
\hline $\begin{array}{l}\text { Butadiene } \\
(1,3- \\
\text { Butadiene) }\end{array}$ & * & $\begin{array}{l}\text { Qccupational Worker } \\
1,000 \mathrm{ppm} \text { TWA }\end{array}$ & 29CFR1910.1000 & $\begin{array}{l}\text { Suspected } \\
\text { Carcinogen }\end{array}$ \\
\hline $\begin{array}{l}\text { Penta- } \\
\text { chloro- } \\
\text { phenol }\end{array}$ & * & $\begin{array}{l}\text { Qccupational Worker } \\
0.5 \mathrm{mg} / \mathrm{m}^{3} \mathrm{TWA}\end{array}$ & 29CFR1910.1000 & $\begin{array}{l}\text { Protection } \\
\text { from skin } \\
\text { contact } \\
\text { required. }\end{array}$ \\
\hline Pyridine & * & $\begin{array}{l}\text { Occupational Worker } \\
5 \text { ppm TWA }\end{array}$ & 29CFR1910.1000 & \\
\hline
\end{tabular}

- In the event that this $\mathrm{COC}$ is identified as being present, the surface will be cleaned to a reasonably achievable level according to the ALARA principle. 


SUBSTANCE $\frac{\text { SURFACE }}{\text { LIMITS }} \quad$ SOURCE AIRLIMITS $\quad$ SOURCE

\begin{tabular}{|c|c|c|c|c|}
\hline $\begin{array}{l}\text { Ethyl } \\
\text { Alcohol } \\
\text { (Ethanol) }\end{array}$ & $*$ & $\begin{array}{l}\text { Occupational Worker } \\
\text { 1,000 ppm TWA }\end{array}$ & 29CFR1910.1000 & \\
\hline $\begin{array}{l}\text { Methyl } \\
\text { Alcohol } \\
\text { (Methanol } \\
\text { ) }\end{array}$ & $*$ & $\begin{array}{l}\text { Occupational Worker } \\
200 \text { ppm TWA } \\
250 \text { ppm STEL }\end{array}$ & $\begin{array}{l}\text { 29CFR1910.1000 } \\
\text { NIOSH Pocket } \\
\text { Guide to Chemical } \\
\text { Hazards USDHHS }\end{array}$ & $\begin{array}{l}\text { Protection } \\
\text { from skin } \\
\text { contact } \\
\text { required. }\end{array}$ \\
\hline \multicolumn{5}{|c|}{ Acids } \\
\hline $\begin{array}{l}\text { Sulfuric } \\
\text { Acid }\end{array}$ & $*$ & $\frac{\text { Qccupational Worker }}{1 \mathrm{mg} / \mathrm{m}^{3} \text { TWA }}$ & 29CFR 1910.1000 & \\
\hline $\begin{array}{l}\text { Nitric } \\
\text { Acid }\end{array}$ & * & $\begin{array}{l}\text { Occupational Worker } \\
2 \text { ppm TWA } \\
4 \text { ppm STEL }\end{array}$ & $\begin{array}{l}\text { 29CFR } 1910.1000 \\
\text { NIOSH Pocket } \\
\text { Guide to Chemical } \\
\text { Hazards USDHHS }\end{array}$ & \\
\hline $\begin{array}{l}\text { Hydro- } \\
\text { chloric } \\
\text { Acid } \\
\text { (Hydrogen } \\
\text { Chloride) }\end{array}$ & * & $\begin{array}{l}\text { Qccupational Worker } \\
5 \text { ppm Ceiling }\end{array}$ & 29CFR1910.1000 & \\
\hline $\begin{array}{l}\text { Hydro- } \\
\text { fluoric } \\
\text { Acid (as } \\
\text { F) } \\
\text { (Hydrogen } \\
\text { Fluoride) }\end{array}$ & * & $\begin{array}{l}\text { Occupational Worker } \\
3 \text { ppm TWA } \\
6 \text { ppm Ceiling }\end{array}$ & $\begin{array}{l}\text { 29CFR1910.1000 } \\
\text { NIOSH Pocket } \\
\text { Guide to Chemical } \\
\text { Hazards USDHHS }\end{array}$ & $\begin{array}{l}\text { Etchant } \\
\text { Solution }\end{array}$ \\
\hline $\begin{array}{l}\text { Chromic } \\
\text { Acid and } \\
\text { Chromates }\end{array}$ & * & $\begin{array}{l}\text { Occupational Worker } \\
0.1 \mathrm{mg} / \mathrm{m}^{3} \text { Ceiling (as } \\
\mathrm{CrO}_{3} \text { ) } \\
0.001 \mathrm{mg} / \mathrm{m}^{3} \mathrm{TWA} \text { (as } \\
\mathrm{Cr} \text { ) }\end{array}$ & $\begin{array}{l}\text { 29CFR1910.1000 } \\
\text { NIOSH Pocket } \\
\text { Guide to Chemical } \\
\text { Hazards USDHHS }\end{array}$ & $\begin{array}{l}\text { Plating } \\
\text { Solution }\end{array}$ \\
\hline
\end{tabular}

* In the event that this $C O C$ is identified as being present, the surface will be cleaned to a reasonably achievable level according to the ALARA principle. 


$\underline{\text { SUBSTANCE }} \frac{\text { SURFACE }}{\text { LIMITS }}$ SOURCE $\quad$ SOURLLIMITS

\section{Bases}

\begin{tabular}{|c|c|c|c|}
\hline $\begin{array}{l}\text { Sodium } \\
\text { Hydroxide }\end{array}$ & * & $\begin{array}{l}\frac{\text { Occupational Worker }}{2 \mathrm{mg} / \mathrm{m}^{3}} \\
\end{array}$ & 29CFR 1910.1000 \\
\hline $\begin{array}{l}\text { Potassium } \\
\text { Hydroxide }\end{array}$ & * & $\begin{array}{l}\text { Occupational Worker } \\
2 \mathrm{mg} / \mathrm{m}^{3}\end{array}$ & $\begin{array}{l}\text { NIOSH Pocket } \\
\text { Guide to Chemical } \\
\text { Hazards USDHHS }\end{array}$ \\
\hline $\begin{array}{l}\text { Aluminum } \\
\text { Sulfate }\end{array}$ & * & $2 \frac{\text { Occupational Worker }}{2 \mathrm{mg} / \mathrm{m}^{3} \text { TWA (as Al) }}$ & $\begin{array}{l}\text { NIOSH Pocket } \\
\text { Guide to Chemical } \\
\text { Hazards USDHHS }\end{array}$ \\
\hline $\begin{array}{l}\text { Nickel } \\
\text { Carbonyl }\end{array}$ & * & $\begin{array}{l}\text { Occupational Worker } \\
0.001 \mathrm{ppm} \mathrm{TWA}\end{array}$ & 29CFR1910.1000 \\
\hline
\end{tabular}

Miscellaneous Chemicals/Particulates

\begin{tabular}{|c|c|c|c|c|}
\hline Asbestos & * & $\begin{array}{l}\text { Occupational Worker } \\
0.1 \text { fiber/cc TWA } \\
1 \text { fiber } / \text { cc in } 30 \mathrm{~min} . \\
\text { period (Excursion Limit) }\end{array}$ & 29CFR1910.1001 & $\begin{array}{l}\text { Confirmed } \\
\text { Carcinogen }\end{array}$ \\
\hline $\begin{array}{l}\text { Fuel, Fuel } \\
\text { Oils, Oils } \\
\text { and Oil } \\
\text { Sludges }\end{array}$ & * & Occupational Worker & & \\
\hline $\begin{array}{l}\text { Gasoline } \\
\text { Oil Mist, } \\
\text { Mineral }\end{array}$ & & $\begin{array}{l}\text { Limits no longer appear } \\
\text { in the Table Z-1-A list. } \\
\text { NIOSH considers it a } \\
\text { potential occupational } \\
\text { carcinogen. } \\
5 \mathrm{mg} / \mathrm{m}^{3} \text { TWA }\end{array}$ & $\begin{array}{l}\text { 29CFR1910.1000 } \\
\text { 29CFR } 1910.1000\end{array}$ & \\
\hline
\end{tabular}

\footnotetext{
- In the event that this $\mathrm{COC}$ is identified as being present, the surface will be cleaned to a reasonably achievable level according to the ALARA principle.
} 


SUBSTANCE $\frac{\text { SURFACE }}{\text { LIMITS }}$ SQURCE AIR LIMITS $\quad$ SOURCE REMARKS

\begin{tabular}{|c|c|c|c|c|c|}
\hline $\begin{array}{l}\text { Inert } \\
\text { Particulate } \\
\text { Material }\end{array}$ & & & $\begin{array}{l}\text { Occupational Worker } \\
50 \mathrm{mg} / \mathrm{m}^{3} \text { TWA (total } \\
\text { dust) } \\
15 \mathrm{mg} / \mathrm{m}^{3} \text { TWA } \\
\text { (respirable fraction) }\end{array}$ & 29CFR1910.1000 & \\
\hline PCBs & $\begin{array}{l}\text { Occupational } \\
\text { Worker } \\
\text { High-Contact } \\
\text { Areas, and } \\
\text { Low- } \\
\quad \text { Contact } \\
\text { Indoor } \\
\text { Impervious \& } \\
\quad \text { Non- } \\
\text { Impervious } \\
\text { Surfaces } \\
10 \text { mg/100 } \\
\text { cm } 2 \\
\\
\text { Encapsulated } \\
\text { Low-Contact } \\
\text { Indoor } \\
\text { Impervious } \\
\text { Surfaces } \\
100 \text { mg/100 } \\
\mathrm{cm}^{2}\end{array}$ & OSHA & $\begin{array}{l}\frac{\text { Occupational Worker }}{0.5 \mathrm{mg} / \mathrm{m}^{3}} \\
\text { ChlorodiphenylTWA } \\
\text { chlorine) } \\
154 \% \\
1 \mathrm{mg} / \mathrm{m}^{3} \text { Chlorodiphenyl } \\
\mathrm{TWA} \quad(42 \% \\
\text { chlorine) }\end{array}$ & 29CFR1910.1000 & $\begin{array}{l}\text { Protection } \\
\text { from skin } \\
\text { contact } \\
\text { required. }\end{array}$ \\
\hline $\begin{array}{l}\text { DDT } \\
\text { (Dichlorod } \\
\text { iphenyltri- } \\
\text { chloroetha } \\
\text { ne) }\end{array}$ & * & & $\begin{array}{l}\text { Gecupational Worker } \\
1 \mathrm{mg} / \mathrm{m}^{3} \text { TWA }\end{array}$ & 29CFR1910.1000 & $\begin{array}{l}\text { Protection } \\
\text { from skin } \\
\text { contact } \\
\text { required. }\end{array}$ \\
\hline
\end{tabular}

- In the event that this $C O C$ is identified as being present, the surface will be cleaned to a reasonably achievable level according to the ALARA principle. 


SUBSTANCE SURFACE SOURCE AIR LIMITS SOURCE REMARKS

\section{Radionuclides}

\begin{tabular}{|c|c|c|c|c|}
\hline $\begin{array}{l}\text { Uranium } \\
\text { (U- } \\
235 \& 238) \\
(\alpha)\end{array}$ & \begin{tabular}{|l}
$\frac{\text { Occupational }}{\text { Worker }}$ \\
1,000 \\
dpm/100 cm 2 \\
(removable) \\
5,000 \\
dpm/100 cm 2 \\
(fixed plus \\
\\
removable) \\
\\
1,000 \\
dpm/100 cm 2 \\
(removable) \\
5,000 \\
dpm/100 cm 2 \\
(average) \\
15,000 \\
dpm/100 cm 2 \\
(max.)
\end{tabular} & $\begin{array}{l}\text { DOE } 5480.11 \\
\text { Reg. Guide } \\
1.86\end{array}$ & $\begin{array}{l}\begin{array}{c}\text { Occupational Worker } \\
0.05 \mathrm{mg} / \mathrm{m}^{3} \mathrm{TWA} \text { (as } \mathrm{U} \text { ) } \\
\text { (soluble }\end{array} \\
\text { compounds) } \\
0.2 \mathrm{mg} / \mathrm{m}^{3} \text { TWA (as U) } \\
\text { (insoluble } \\
\text { compounds) } \\
0.6 \mathrm{mg} / \mathrm{m}^{3} \text { STEL (as U) } \\
\quad \text { (insoluble } \\
\text { compounds) } \\
\mathrm{U}^{235} \text { and } \mathrm{U}^{238} \\
6 \times 10^{-10} \mu \mathrm{Ci} / \mathrm{ml} \text { (very } \\
\text { soluble) } \\
3 \times 10^{-10} \mu \mathrm{Ci} / \mathrm{ml} \\
\text { (soluble) } \\
2 \times 10^{-11} \mu \mathrm{Ci} / \mathrm{ml} \\
\text { (insoluble) } \\
\mathrm{U}^{235} \text { and } \mathrm{U}^{238} \text { (DACs) } \\
6 \times 10^{-10} \mu \mathrm{Ci} / \mathrm{ml} \text { (very } \\
\text { soluble) } \\
3 \times 10^{-10} \mu \mathrm{Ci} / \mathrm{ml} \text { (soluble) } \\
2 \times 10^{-10} \mu \mathrm{Ci} / \mathrm{ml} \\
\text { (insoluble) }\end{array}$ & $\begin{array}{l}\text { 29CFR1910.1000 } \\
\text { 10CFR835, } \\
\text { Appendix A } \\
\text { DOE 5480.11 } \\
\text { 6CCR 1007-1, Pt. } \\
4 \\
\text { Appendix B }\end{array}$ \\
\hline
\end{tabular}

- In the event that this $C O C$ is identified as being present, the surface will be cleaned to a reasonably achievable level according to the ALARA principle. 


SUBSTANCE $\frac{\text { SUREACE }}{\text { LIMITS }} \quad$ SOURCE SIR LIMITS $\quad$ SOURCE REMARKS

\begin{tabular}{|c|c|c|c|c|}
\hline $\begin{array}{l}\text { Alpha } \\
\text { (Transuran } \\
\text { ics) } \\
(\alpha)\end{array}$ & $\begin{array}{l}\frac{\text { Occupational }}{\text { Worker }} \\
20 \frac{\mathrm{dpm} / 100}{\mathrm{~cm}^{2}} \\
\text { (removable) } \\
300 \mathrm{dpm} / 100 \\
\mathrm{~cm}^{2} \text { (fixed } \\
\text { plus } \\
\text { removable) } \\
20 \text { dpm/100 } \\
\mathrm{cm}^{2} \\
\text { (removable) } \\
100 \text { dpm/100 } \\
\mathrm{cm}^{2} \text { (average) } \\
300 \text { dpm/100 } \\
\mathrm{cm}^{2} \text { (max.) }\end{array}$ & $\begin{array}{l}\text { DOE } 5480.11 \\
\text { Reg. Guide } \\
1.86\end{array}$ & $\begin{array}{l}\text { Based upon the values } \\
\text { for the individual Alpha } \\
\text { emitting elements, i.e., } \\
\text { Transuranics, } \mathrm{Ra}^{226} \text { and } \\
\mathrm{Ra}^{228} \text {. }\end{array}$ & \\
\hline $\begin{array}{l}\text { Beta- } \\
\text { Gamma } \\
(w / e x \\
\text { Sr } 90) \\
(\beta-\gamma)\end{array}$ & $\begin{array}{l}\frac{\text { Occupational }}{\text { Worker }} \\
1,000 \\
\text { dpm/100 cm } \\
\text { (removable) } \\
5,000 \\
\text { dpm/100 cm } 2 \\
\text { (fixed plus } \\
\\
\text { removable) } \\
\\
1,000 \\
\text { dpm/100 cm } 2 \\
\text { (removable) } \\
5,000 \\
\text { dpm/100 cm } 2 \\
\text { (average) } \\
15,000 \\
\text { dpm/100 cm } \\
\text { (max.) }\end{array}$ & $\begin{array}{l}\text { DOE } 5480.11 \\
\text { Reg. Guide } \\
1.86\end{array}$ & $\begin{array}{l}\text { Based upon the values } \\
\text { for the individual Alpha } \\
\text { emitting elements, i.e., } \\
\text { Th234. }\end{array}$ & $\begin{array}{l}\mathrm{Sr}^{90} \text { has the } \\
\text { same surface } \\
\text { contamination } \\
\text { values as } \\
\text { Radon. }\end{array}$ \\
\hline
\end{tabular}

- In the event that this $\mathrm{COC}$ is identified as being present, the surface will be cleaned to a reasonably achievable level according to the ALARA principle. 


\section{SUBSTANCE SURFACE SOURCE SIR LIMITS SOURCE REMARKS LIMITS}

\begin{tabular}{|c|c|c|c|c|}
\hline $\begin{array}{l}\text { Radon } \\
\left(\mathrm{Rn}^{220}\right. \\
\left.\mathrm{Rn}^{222}\right) \\
\text { and its } \\
\text { daughter } \\
\text { products }\end{array}$ & $\begin{array}{l}\frac{\text { Occupational }}{\text { Worker }} \\
200 \text { dpm } / 100 \\
\mathrm{~cm}^{2} \\
\text { (removable) } \\
1,000 \\
\text { dpm/100 cm } 2 \\
\text { (fixed plus } \\
\\
\text { removable) } \\
\\
200 \text { dpm/100 } \\
\text { cm } 2 \\
\text { (removable) } \\
1,000 \\
\text { dpm/100 cm } 2 \\
\text { (average) } \\
3,000 \\
\text { dpm/100 cm } 2 \\
\text { (max.) }\end{array}$ & $\begin{array}{l}\text { DOE } 5480.11 \\
\text { Reg. Guide } \\
1.86\end{array}$ & 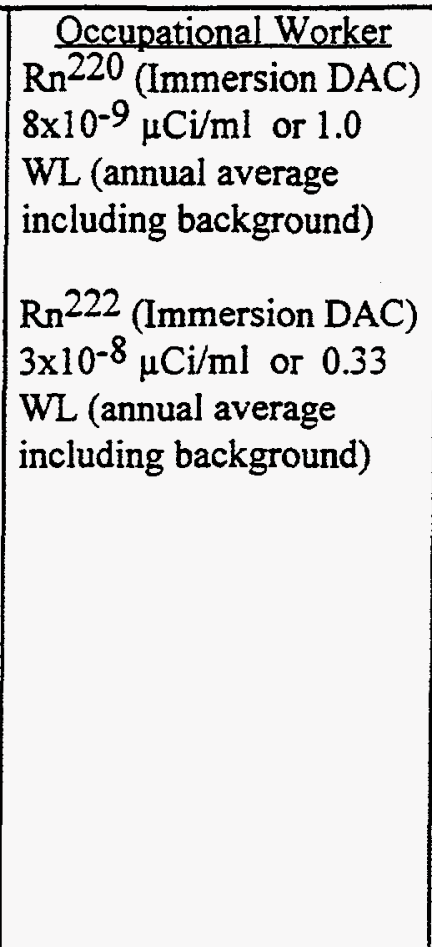 & $\begin{array}{l}\text { 10CFR835, } \\
\text { Appendices A\&C } \\
\text { DOE 5480.11 } \\
\text { 10CFR835, } \\
\text { Appendices A\&C } \\
\text { DOE 5480.11 }\end{array}$ \\
\hline
\end{tabular}

\section{Abbreviations:}

DAC $=$ Derived Air Concentration

IAW $=$ In Accordance With

PEL $=$ Permissible Exposure Limit

STEL $=$ Short Term Exposure Limit

TWA $=$ Time Weight Average (over an 8 hour workshift)

$\mathrm{WL}=$ Working Level $(100 \rho \mathrm{Ci} / \mathrm{l})$

\footnotetext{
- In the event that this $\mathrm{COC}$ is identified as being present, the surface will be cleaned to a reasonably achievable level according to the
} ALARA principle. 


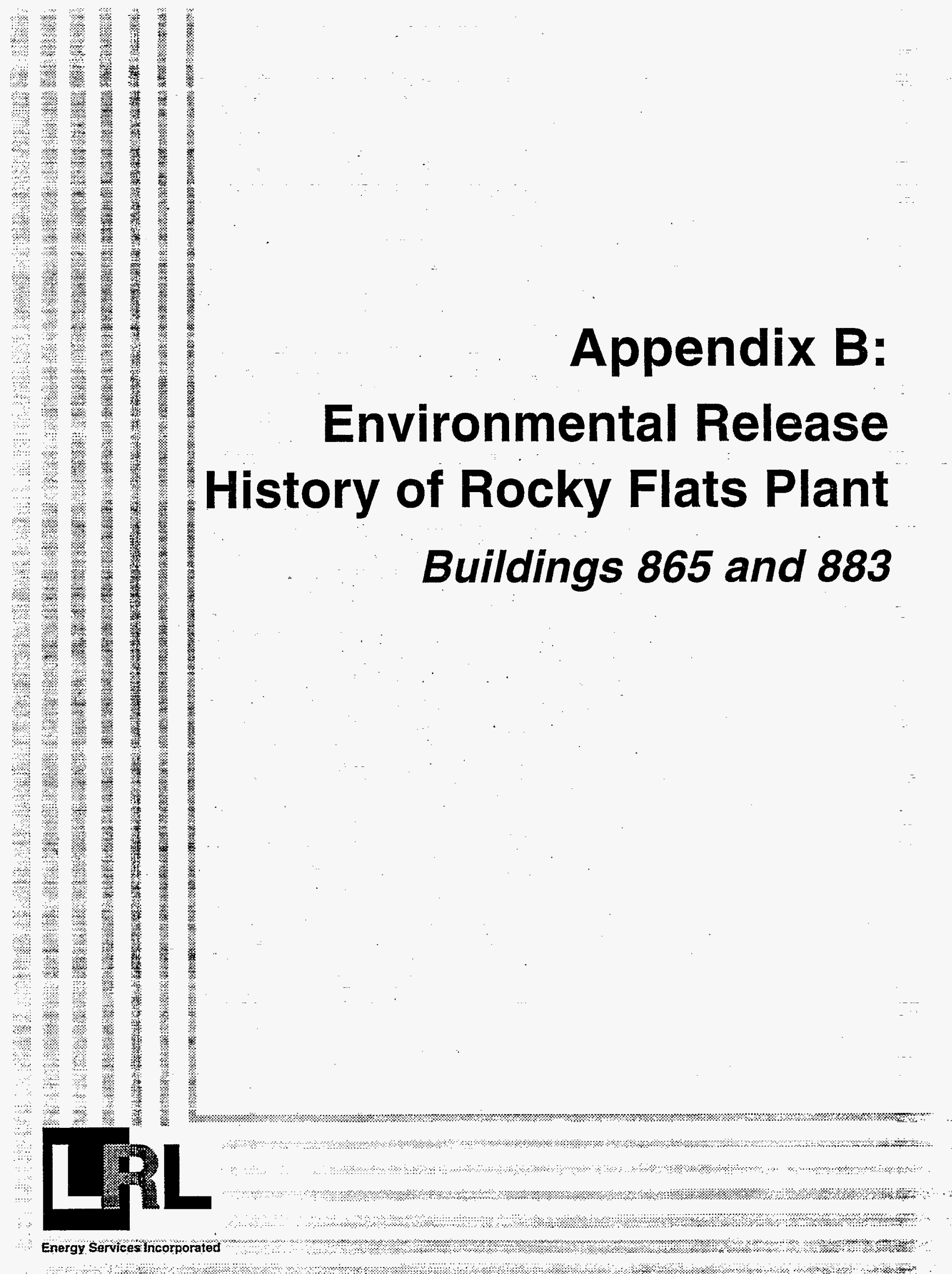




\section{Environmental Incident History of Rocky Flats Plant Buildings 865 and 883}

\section{Introduction}

Throughout the life of the RFETS, data on spills and other environmental incidents have been tabulated. This data is contained in the Rocky Flats Historical Release Report, dated 1992. A listing of historical releases, excerpted from the Historical Release Report, is shown on the following pages. All of the action items resulting from these releases have been closed out. 


\section{PAC REFERENCE NUMBER: 800-180}

IHSS Reference Number. 180

Unit Name: Building 883 Drum Storage Area

Approximate Location: N748,500; E2,084,000

Date(s) of Operation or Occurrence

1981 - Present ${ }^{1}$

Description of Operation or Occurrence

The Building 865 Drum Storage Area was first used in 1981 and is currently issed as a RCRA 90-day accumulation area. The storage area occupies Room 104 which measures 16 feet by 10 feet. The maximum number of 55 gallon drums stored there is thinty. They are stored directly on a concrete floor with no berms or floor drains. ${ }^{1}$

\section{Physical/Chemical Description of Constiments Released}

The drums stored there contain waste oils that are usually contaminated with solvents and uranium. Analytical results have indicated the presence of volatile organic compounds, beryllizim and radioactivity. There have been no documented releases and, based on a visual inspection in November 1986, there was no evidence of spills or leakage.'

\section{Responses to Operation or Occurrence}

No documentation was found that details any response to this operation.

\section{Fate of Constituents Released to Environment}

This IHSS is being studied in accordance with the IAG schedule of OU15. However, the information developed on this unit for this study indicates flat the IHSS location presented in the IAG is inaccurate. The IAG activities will include site investigation, site characterization, and possible site remediation. The Final Phase I RFIRI is to be completed by January 4,8995 .

\section{Comments}

The site was locased in IAG to include all of Building 883. It is proposed that the PAC boundaries be changed to include only Rooni 104.

\section{References}

${ }^{1}$ U.S. DOE, Container Storage Facilities Closure Plan, April 5, 1988. 
IHSS Reference Number: 179

Unit Name: Building 865 Drum Storage Area

Approximate Location: N749,000; E2,084,000

Date(s) of Operation or Occurrence

1970 - Present ${ }^{1}$

Description of Operation or Occurrence

The Building 865 Drum Storage Area was first used in 1970 and is currently used as a RCRA 90-day accumulation area. The storage area is in Room 145 and measures 12 feet by 8 feet. The maximum number of 55 gallon drums stored there is ten. They are stored directly on a concrete floor with no berms or floor drains. ${ }^{1}$

\section{Physical/Chemical Description of Constiments Released}

The drums stored there today contain volatile organic compounds, beylifium, and radioactive waste. In the past, chlorinated solvents were also stored there. There have been no docainented releases and, based on a visual inspection in November of 1986, there was no visual evidence of spills.'

\section{Responses to Operation or Occurrence}

No documentation was be found that details any response to this operation.

\section{Fate of Constituents Released to Enviromiment}

This IHSS is being studied in accordance, with the IAG schedule of OU15. However, the information developed on this unit for this study indicates that the IIISS location presented in the IAG is inaccurate. The IAG activities will include site investigations, stectiaracterizations, and possible site remediation. The Final Phase I RFI/RI is to be completed by January 4,1995 .

\section{Comments}

The need for a 90-day accumulation point in this area is currently under review. The site was located in the IAG to include all of Building 865. It is proposed that the PAC boundaries be changed to include only Room 145.

\section{$\underline{\text { References }}$}

${ }^{1}$ U.S. DOE, Container Storage Facilities Closure Plan, April 5, 1988. 
IHSS Reference Number: Not Applicable

Unit Name: Valve Vault 2

Approximate Location: N749,000; E2,084,000

Date(s) of Operation or Occurrence

April 25, 1989

Description of Operation or Occurrence

During a routine inspection of Valve Vault 2 on April 25, 1989 liquid was discovered in the leak detection collection bottle. ${ }^{2}$ The bottle was also leaking, therefore, the alarm was not sounded? ${ }^{3}$. The leak was coming from the south process transfer line which consists of a three-inch PVC schedule-80 pipe inside a six-inch polyethylene chase pipe (containment pipe). ${ }^{4} \mathrm{~A} \mathrm{pH}$ check of the liquid indicated that the inner pipe, which originates from waste tanks in Building 883 , was leaking. ${ }^{4}$ Three discharges had occurred through this line since the vault was last inspected (March 14, 1989), at which time no leakage was apparent. ${ }^{3}$

\section{Physical/Chemical Description of Constituents Released}

Building 883 generates a process waste that is nitric acid and/or rinsate water contaminated with depleted uranium..$^{6}$ A pH check of the liquid showed a $\mathrm{pH}$ of $/ \mathrm{V}^{2}{ }^{2}$. The waste is partially neutralized with roughly equal amounts of a potassium hydroxide solution before it is discharged to Building 374 via Valve Vault 2 . $^{6}$ Table 800-1 summarizes the maximum potential release to the environment and analytical results from samples taken during the three transfers prior to discovery of the leak:

TABLE 800-1

SUMMARIZATHON OF WASTE STREAM FROM BUILDING $883^{6}$

\begin{tabular}{|c|c|c|c|c|}
\hline DATE & $\begin{array}{l}\text { TOTAL } \\
\text { ALPHY } \\
\text { ACTIVITY } \\
\text { (PCi/1) }\end{array}$ & $\mathrm{pH}$ & $\begin{array}{c}\mathrm{Be} \\
(\mathrm{ppm})\end{array}$ & $\begin{array}{l}\text { ESTIMATED } \\
\text { MAXIMUM } \\
\text { RELEASE } \\
\text { (Gallons) }\end{array}$ \\
\hline $03 / 15 / 89$ & $1.6 \times 10^{6}$ & 1.5 & $<0.1$ & 5 \\
\hline $03 / 16 / 89$ & $3.9 \times 10^{7}$ & 3.2 & $<0.1$ & $\begin{array}{c}7 \text { (> } 1 \text { lbs } \\
\text { radionuclides) }\end{array}$ \\
\hline $04 / 13 / 89$ & $1.7 \times 10^{5}$ & 14 & $<0.1$ & $\begin{array}{c}15 \text { (> } 100 \mathrm{lbs} \\
\text { corrosives) }\end{array}$ \\
\hline
\end{tabular}

\section{Responses to Operation or Occurrence}

Upon detection of the leak, discharge valves from the waste tanks in Building 883 were closed and locked out. Plumbing changes took place within two days after the leak was detected to insure no more transfers were made through this line. ${ }^{3}$ Hydrostatic testing of the inner line began on May 8, 1989 and continued through the month. ${ }^{2}$ Removal of the inner line began in May 29 and continued through June 2. Salt encrustations were found at the elbow where the process waste line exits the nitrad pickling operation room. ${ }^{3}$ 
During the week of June 5-9, 1989 the secondary chase pipe was hydrostatically tested. ${ }^{4}$ When it was found to be leaking, the line was inspected by electronic visual imaging on June 15, 1989 to locate the leak. Soil sampling had not begun as of July $31,1989 .^{4}$

Because the release amounts exceed the reportable quantity, the event was reported to the National Response Center on June 15, 1989.5 A RCRA Contingency Plan (Implementation Report No. 89-007) was submitted in compliance with 6 CCR 1007-3, Part 265.56(j). ${ }^{6}$

\section{Fate of Constiments Released to Environment}

No documentation was found which detailed the fate of constituents released to the environment. No sampling had taken place at the time these references were written. It is not known to what extent the environment was effected. Surface drainage and ground water movement would be toward Woman Creek.

\section{Comments}

None.

\section{References}

1 RFP Utility Drawings, Drawing 15501-43-M, January 17, 1987.

21500265

31500262

41500264

5 1500263

- 1700780 
PAC REFERENCE NUMBER: 800-1201

IHSS Reference Number. Not Applicable

Unit Name: Radioactive Site South of Building 883

Approximate Location: N748,500; E2,084,000

Date(s) of Operation or Occurrence

$1958-1981$

\section{Description of Operation or Occurrence}

Contamination in the area between Buildings 883 and Building 881 is documented as early as 1958. After the plutonium fire in 1957, studies were initiated to determine the spread of contamination. This study was extended to research the impact of Rocky Flats Plant operations on the enviromment. One particular spot in the 800 area with significant plutonium contamination was located 500 feet east of the 881 Building road and 500 feet north of Building 881 (prior to construction of Building 883). ${ }^{\prime}$

In 1978, while conducting field surveys during excavation for a teleptone line, readings above background were found about 30 feet south of Building $883 .^{2}$ Radiometric soil surveys found two other spots, one at the northwest comer of Building 889 and the other at the southeast comer of Building $865 .^{3}$

\section{Physical/Chemical Description of Constituents Released}

In 1958, soil samples were taken at the northwest comer of Building 881 and 20 feet west of the building. Analysis indicated total activity of $4.5 \times 10^{4} \mathrm{~d} / \mathrm{m} / \mathrm{kg}$ and $1.5 \times 10^{5} \mathrm{~d} / \mathrm{m} / \mathrm{kg}$, respectively, with some plutonium.' During the excavation in 1978 , the soil samples were found to contain uranium-235. ${ }^{2}$

\section{Responses to Operation or Occurrence}

No documentation of cleanup activities was found in response to the 1958 incident. Removal of contaminated soil in two small areas near Building 883 was completed in April of $1981 .^{4}$ It is not known if these are the contaminated areas mentioned in 1978 .

\section{Fate of Constituents Released to Enviroriment}

No documentation was found which detailed the fate of constituents released to the environment.

\section{Comments}

No documentation was found which explained these hot spots.

\section{References}

1700390

21600206

${ }^{3} 1700194$

${ }^{4} 1501181$ 


\section{Other Reference of Interest}

1600204 


\section{PAC REFERENCE NUMBER: 800-1202}

IHSS Reference Number. Not Applicable

Unit Name: Sulfuric Acid Spill, Building 883

Approximate Location: N749,000; E2,084,000

\section{Date(s) of Operation or Occurrence}

October 21, 1985

\section{Description of Operation or Occurrence}

A battery fell from a fork lift or truck. Acid was spilled in the middle of the roadway outside Door \#11 of Building 883.'

\section{Physical/Chemical Description of Constituents Released}

Approximately one quart to one-half gallon of sulfuric acid was spilled on the roadway.

\section{Responses to Operation or Occurrence}

Sodium bicarbonate was applied to the spill and the area washed down. No radioactive contamination was involved. ${ }^{1}$ The battery was disposed of in the present landfill (PAC NW-114).

\section{Fate of Constiments Released to Environment}

No documentation was found which detailed the fate of constituents released to the environment.

\section{Comments}

None.

$\underline{\text { References }}$

1600546 
PAC REFERENCE NUMBER: $800-1203$

IHSS Reference Number. Not Applicable

Unit Name: Sanitary Sewer Line Break Between Building 865 and 886

Approximate Location: N749,000; E2,084,000

Date(s) of Operation or Occurrence

June 1982

Description of Operation or Occurrence

In June 1982 , construction crews broke the sanitary sewer line between Building 865 and Building $886 .{ }^{1}$

Physical/Chemical Description of Constituents Released

An unknown quantity of sanitary sewage waste was released.

\section{Responses to Operation or Occurrence}

No documentation was found which indicated that the line was repaired or replaced.

Fate of Constituents Released to Environment

The sewage did not reach the Central Avenue ditch; therefore, it was considered at the time that no impact was made on the downstream ponds. ${ }^{1}$

Comments

None.

References

${ }^{1} 1700468$ 
IHSS Reference Number. Not Applicable

Unit Name: Building 866 Spills

Approximate Location: N749,000, E2,084,000

Date(s) of Operation or Occurrence

1965 (Date of building occupancy) - Present

Description of Operation or Occurrence

Building 886 holds five process waste tanks that service Building 865 and Building 889 . Contamination releases originating from the filling of the tanks have been documented.

\section{January, 1978 - Vent Pipe Overflow}

A faulty vacuum breaker for a process waste line vent pipe berween Building 864 and Building 881 allowed liquid to be released to the environment. ${ }^{12}$ Apparently gravel caused the vent line to stick open and approximately two gallons spilled onto the ground. ${ }^{3}$ About sixteen square feet were affected near the 865 Guard Post. $^{12}$

\section{4 - Tank overflow}

A valve was left open while pumping decontamination water to a fill tank in Building 889 . When the tank overfilled, the water ran to the sump pump and was then pumped to the process waste tanks in Building 865 . These tanks also overfilled and the water passed up through the vent to the roof where it drained to the ground through the downspouts." A similar incident occurred in 1983 but apparently the water ran into Building 866 instead of outside. ${ }^{5}$

1986 - Tank overflow

While filling the process waste tanks in Building 866, they overflowed out the roof vent and out the downspout releasing approximately 20 gallons to the ground. No contamination was found on the ground or in the building. ${ }^{6}$

\section{Physical/Chemical Description of Constituents Released}

In 1978, laboratory enalysis of the liquid indicated 410,000 disintegrations per minute per liter alpha activity. ${ }^{1.3}$ It consisted of predominately depleted uranium activity. FIDLER survey did not display anything above background readings.'

In 1984, water samples taken from the north and south ditch revealed $2.2 \times 10^{3}$ microgram/liter for total uranium and a maximum of $7.9 \times 10^{2}$ picocuries/iter $(\mathrm{pCi} / 1)$ and $5.8 \times 10^{2} \mathrm{pCi} /$ for total beta activity and tritium, respectively. ${ }^{4}$

In 1986, the spill consisted of process waste. No contamination was found on the ground or in the building. ${ }^{6}$ 


\section{Responses to Operation or Occurrence}

In 1978, samples of the liquid were taken and radiation surveys were conducted. A portable air sampler was utilized and the day following the incident three inches of moist gravel were removed. ${ }^{1}$

In 1984, the drainage ditch west of Building 866 was dammed with gravel to contain the liquid. Mention is made of decontamination of the interior of Building 866 and Building 889 but radiation monitoring indicated no contamination. Surface gravel from the area of the overflow was supposed to have been removed and shipped as waste. Forty to forty-five gallons of liquid were vacuumed up and taken to Buildings 889 waste drains.

In 1986, liquid level alarms were installed for each tank. ${ }^{6}$

Fate of Constituents Released to Environment

No documentation was found which detailed the fate of constituents release to the environment.

\section{Comments}

None.

References

${ }^{1} 1501235$

${ }^{2} 1500989$

${ }^{3} 1600189$

4 1600423

s 1600422

${ }^{6} 1501067$ 
IHSS Reference Number. Not Applicable

Unit Name: Fire, Building 883

Approximate Location: N749,000; E2,084,000

Date(s) of Operation or Occurrence

October, 27, 1982

Description of Operation or Occurrence

A contaminated trash container fire occurred in Building 883 due to grinding operatsons. Maintenance personnel placed the container outside the building and left it unattended. The Fire Deparment responded and spread the contents on the ground ${ }^{1}$

Physical/Chemical Description of Constituents Released

No documentation was found which detailed constituents relezsed, except that the container contained contaminated trash. ${ }^{3}$

\section{Responses to Operation or Occurrence}

The reference states that the Shift Superintendent was resporsible for improper cleanup activities and that Health Physics would be following up on the incident with the proper deparment.

Fate of Constituents Released to Environment

No documentation was found which detalled the fate of constituents released to the environment.

\section{Comments}

None.

References

' 1501039 
IHSS Reference Number: Not Applicable

Unit Name: Transformer $883-4$

Approximate Location: N749,000; E2,084,000

Daters) of Operation or Occurrence

$1985-1987$ or $1988^{1}$

Description of Operation or Occurrence

Transformer 833-4 is located at the southeast comer of Building 883. Utititities reported that it may have leaked prior to being retro-filled. The original pad was partially removed to make room for a new pad that was constructed several feet to the west. What remains of the old pad is now located in a rock filled area with its decomposed berm. After retro-filling, the transformer was placed on the new pad.' It is uncertain when these activities took place.

The transformer. was inspected on November 7, 1985 and was found to leak. ${ }^{2}$ Leakage was also found on January 30,1986 by the EPA. An audit was conducted to determine RFP's compliance with the Toxic Substance Control Act and EPA regulations with respect to PCBs. ${ }^{3}$ This transformer was on the list for cleanup and/or repair on February 11, 1986 due to leakage around the top and bottom valves and oil on the surface of the pad and the transformer itself."

Physical/Chemical Description of Constituents Released

Transformer 883-4 was found to contain greater than 500 ppm PCBs. ${ }^{3}$

\section{Responses to Operation or Occurrence}

The site was not directly inspected by an ERA representative in 1986 but it was required that the transformer be removed or replaced by Fiscal. Year 1987 or $1988 .^{3}$

\section{Fate of Constituents Released to Enviroment}

The area drains to an access road/roughly six feet from the old pad. ${ }^{1}$

\section{Comments}

There was no information to indicate that the spill drained to the access road.

\section{References}

${ }^{1}$ EG\&G Rocky Flats, "Assessment of Known, Suspect, and Potential Environmental Releases of Polychlorinated Biphenyls (PCBs)", October, 1991.

21700068

${ }^{3} 1700000$

${ }^{4} 1700070$ 


\section{Other Reference of Interest}

1700076 


\section{PAC REFERENCE NUMBER: 800-1209}

IHSS Reference Number: Not Applicable

Unit Name: Leaking Transformers, 800 Area

Approximate Location: N749,000; E2,084,000

Date(s) of Operation or Occurrence

Unknown - $1991^{1}$

\section{Description of Operation or Occurrence}

Three transformers and a gear switch apparatus are located one hundred feet north of Building 883. Utilities persomel reported that all components within this complex may have leaked prior to being retro-filled in $1987 .{ }^{1}$ All three transformers and the gear switch are currently active. Oil stains were visible at the valve of one of the transformers in a 1991 inspection. $^{1}$

The area is bermed with rock and gravel placed inside and outsite of the berm. There are no drains at this site. ${ }^{1}$

\section{Physical/Chemical Description of Constiments Released}

Utilities personnel suspect that PCBs may have leaked at this site. ${ }^{1}$

\section{Responses to Operation or Occurrence}

The units were retro-filled in 1987.

Fate of Constiments Released to Enviromiment

No documentation was found which indicated a release to the environment occurred at this site.

\section{Comments}

None.

\section{$\underline{\text { References }}$}

${ }^{1}$ EG\&G Rocky Hats: "Assessmeit of Known, Suspect, and Potential Environmental Releases of Polychlorinated Biphenyls (PCBs) ${ }^{2}$. October, 1991. 
IHSS Reference Number: Not Applicable

Unit Name: Transformers $865-1$ and $865-2$

Approximate Location: N749,000; E2,084,000

\section{Date(s) of Operation or Occurrence}

Unknown - $1987^{1}$

\section{Description of Operation or Occurrence}

Transformers 865-1 and 865-2 are located north of Building 886 and westof Building 865. Utilities personnel indicate that they have leaked in the past. In 1987, the transformers were removed, resio-filled and placed on a new pad with berms, several feet to the north. The old pad was parially removed to make room for the new pad. It is unknown whether the old pad had berm containment features?

\section{Physical/Chemical Description of Constituents Released}

The fact that these transformers were retro-filled indicates that PCBs may have been involved.

\section{Responses to Operation or Occurrence}

The transformers were removed from the old pad, retro-filled and placed on a new pad. 1

Fate of Constituents Released to Environment

No documentation was found which detailed the fate of constituents released to the environment.

\section{Comments}

None.

\section{References}

' EG\&G Rocky Flats, "Assessmentof Known, Suspect, and Potential Environmental Releases of Polychlorinated Biphenyls (PCBs)", October, 199\% 
IHSS Reference Number. Not Applicable

Unit Name: Capacitor Leak, Building 883

Approximate Location: N749,000; E2,084,000

Date(s) of Operation or Occurrence

July 5, 1988

Description of Operation or Occurrence

A capacitor was found leaking at the south entrance of Building $883 .^{2}$

Physical/Chemical Description of Constituents Released

The spill involved approximately one pint of oil. A smear sample revealed negative results for PCBs. ${ }^{1}$

\section{Responses to Operation or Occurrence}

A smear sample was taken from the concrete where the leak occurred. $\$$.glass bottle was placed under the leak and absorbent pads were put on the spill and the area was barricaded. ${ }^{1}$

Fate of Constiments Released to Environment

No documentation was found which detailed the fate of constituents released to the environment.

\section{Comments}

None.

\section{References}

${ }^{1} 1700091$ 


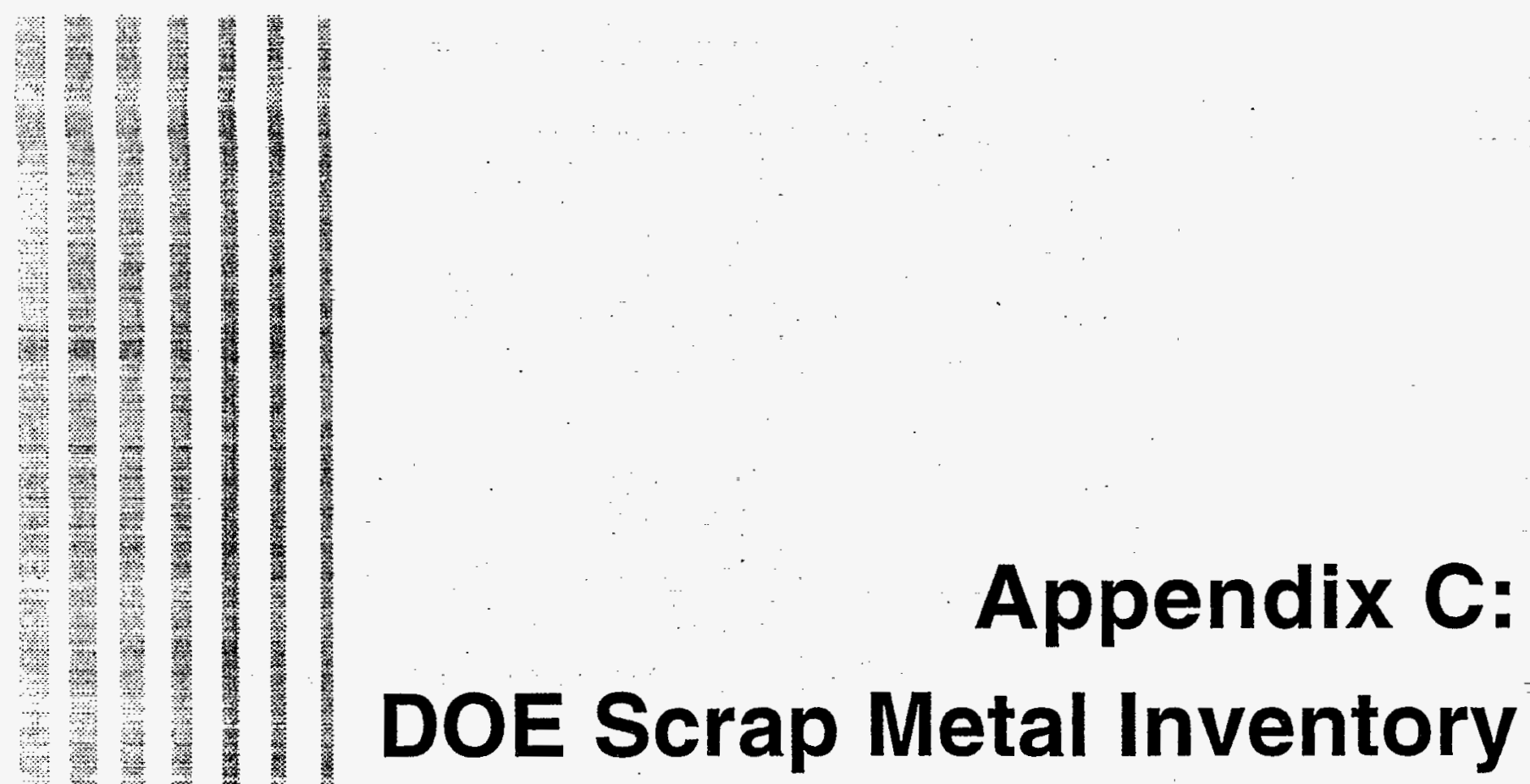




\section{Materials in Inventory Scrap Metal and Equipment Report - EXECUTIVE SUMMARY}

\section{BACKGROUND}

The Department has accumulated a large inventory of scrap metal over the past 50 years. This inventory includes worn or superfluous metal parts or pieces, material found in past storage and lay-down yards, and material generated by decommissioning buildings and facility maintenance and renovation. Similarly, the Department has accumulated thousands of pieces of equipment used for construction, production, manufacturing, and research as well as all of the associated spare parts and hand tools to maintain the equipment.

The scrap metal and equipment inventories are not static; the Department will continue to excess equipment and generate scrap metal through facility decommissioning, manufacturing, production operations, and research activities in the future. The 1995 Sanford Cohen $^{41}$ study for EPA projected that future decommissioning will generate 1.06 million tons of radioactivelycontaminated scrap metal. Because this study only encompassed decommissioning projects at Oak Ridge Gaseous Diffusion Plants (K-25, Paducah, and Portsmouth), Hanford, Savannah River Site (SRS), Weldon Spring, Idaho National Engineering Laboratory (INEL), and Fernald, this figure underestimates the actual amount of scrap metal that the Department will have to manage, store, and disposition in upcoming years.

\section{DefintTion of MIN ScRap METal aND EQuIPMENT}

The Department defines "materials in inventory" as all materials in storage at DOE-owned facilities that are not currently in use, that have not been designated as waste, and that have not been set aside by the Nuclear Weapons Council. For the MIN Initiative, the Department defines "not currently in use" as materials that have not been used during the past year and are not reasonably expected to be used in the coming year. The Scrap Metal and Equipment Team defined MIN scrap metal as follows:

Scrap metal comprises worn or superfluous metal parts or pieces, including but not limited to structural steel and other metals from decommissioned buildings, scrap metals accumulated from facility maintenance and renovation in the past, and scrap stored in scrap yards and lay-down yards. Scrap metal includes metals that are clean and metals contaminated or activated with radioactivity and/or contaminated with hazardous substances.

Structural metals that are still part of buildings that have not yet been decommissioned and scrap metal that already has been buried are excluded from the MIN Initiative. Similarly, precious metals are excluded from the MIN Initiative, except where they can be clearly identified as scrap. Scrap metal that is excessed yearly or more frequently is discussed in this report, but is not considered to be materials in inventory.

Equipment is defined for purposes of the MIN Initiative as all equipment used for construction, production, or manufacturing and all associated spare parts and hand tools.

MIN equipment does not include the following equipment items: items covered by other MIN teams; items loaned or leased by the Department; items that are "consumable"; and items that have been excessed by the cognizant property management organizations. 


\section{Methodology and Data Limitations}

The MIN Scrap Metal and Equipment Team identified what scrap metal or equipment at the site fell within the MIN definition, quantified and characterized these materials in inventory, and characterized the management and disposition practices employed by the site. The Scrap Metal and Equipment Team conducted conference calls, sent out surveys, used existing documentation, and reviewed inventory databases for the MIN Initiative.

Identifying and quantifying equipment that has not been used for the past year and has no designated use for the coming year was complicated by three factors: (1) the Department's property information systems vary from site to site; (2) they are not centrally accessible; and (3) they are not set up to readily identify equipment that meets the definition of materials in inventory. Furthermore, equipment is not easily quantified by weight or volume. Because of these information constraints, the MIN Scrap Metal and Equipment Team decided to quantify the MIN equipment inventory by acquisition value, expressed in dollars.

\section{INVENTORY}

As shown in Table B-4, the Department stores almost 155,000 tons of non-precious scrap metal at 18 sites across the nation.

Approximately 90 percent of the MIN scrap metal inventory is located at five sites:

Paducah, K-25, SRS, Y-12, and Portsmouth (Figure B-5). The Department estimates this inventory to be worth almost $\$ 80,000,000$ (assuming no contamination).

As shown in Figure B-6, the MIN Scrap Metal and Equipment Team reported seven types of scrap metal. Carbon steel comprises over 77 percent of MIN scrap metal. Aluminum, stainless steel, and nickel comprise
Table B-4. Quantities and Value of Non-Precious MIN Scrap

\begin{tabular}{|l|r|r|}
\hline \multicolumn{1}{|c|}{ Site } & Scrap (tons) & \multicolumn{2}{|c|}{ Value (\$) } \\
\hline ANL-W & 26 & 13,929 \\
BNL & 662 & 400,117 \\
Fermilab & 6,760 & 650,654 \\
Fernald & 5,115 & $2,630,950$ \\
Hanford & 2,516 & Not Reported \\
INEL & 2,300 & 813,170 \\
K-25 & 36,699 & $4,470,213$ \\
LBL & 168 & Not Reported \\
NTS & 331 & 32,627 \\
ORNL & 1,411 & 261,290 \\
PGDP & 60,473 & $60,880,138$ \\
Pantex & 290 & 27,201 \\
Portsmouth & 11,143 & $1,329,784$ \\
RMI & 70 & 6,575 \\
SLAC & 17 & 12,550 \\
SRS & 15,533 & $5,17,228$ \\
WIPP & 103 \\
Y-12 & 11,332 & 11,360 \\
Total & 154,949 & $1,730,612$ \\
\hline
\end{tabular}

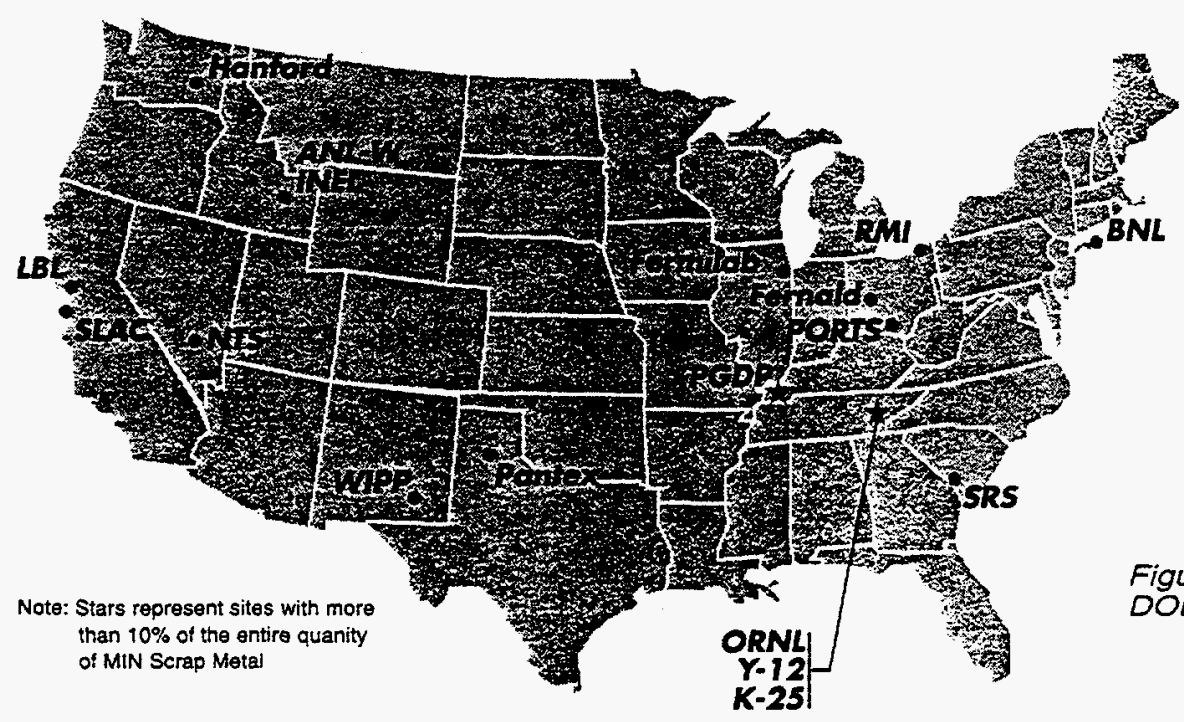

Figure B-5. Geographic Distribution of DOE Sites Storing MIN Scrap Metal 
approximately 16 percent of the MIN scrap metal inventory. Figure B-6 also illustrates that nickel comprises approximately 67 percent of the entire value of MIN scrap metal. The contamination of approximately 80 percent of MIN scrap metal is unspecified because the scrap metal inventory at Oak Ridge is uncharacterized. The Department also stores over 10,000 troy ounces of MIN scrap precious metal at eight sites. The estimated value of this inventory is approximately $\$ 2.5$ million.

\section{Current Management Practices}

\section{Storage Conditions}

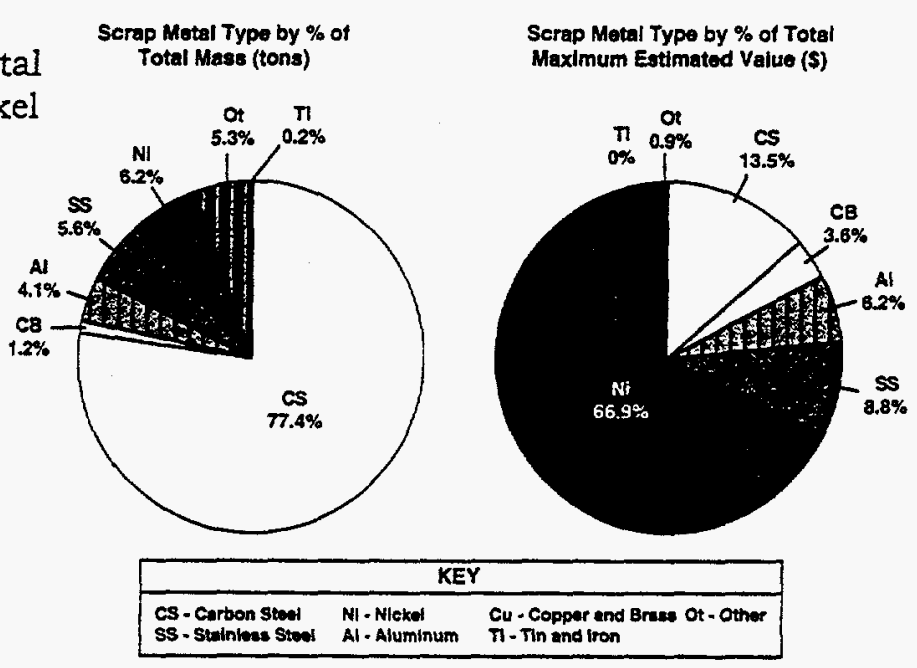

Figure B-6. MIN Scrap Metal inventory Comparison of Metal Types and Values

- Scrap Metal - Three types of storage configurations exist: open lay-down yards, containers, and scrap metal piles.

- Scrap Precious Metal - The Department has specific policies, principals, and guidelines for managing and storing scrap precious metals. Sites designate custodians to ensure that appropriate physical and administrative controls are in place and enforced.

- Equipment - Four types of management systems track equipment using asset codes: property tracking, warehouse tracking, site-specific spares and materials tracking, and excess/surplus tracking. Asset codes refer to types of equipment and are used to tag and track all acquired equipment through the complex.

\section{Inspections and Monitoring}

- Scrap Metal - Custodians monitor radioactively or chemically contaminated scrap metal.

- Scrap Precious Metal - Custodians prepare monthly reports that are reconciled with the property accounting report for these materials. This is supplemented by biannual physical inventories to ensure complete accountability.

- Equipment - Property management walk-through inspections are conducted in all operating and storage areas once every two years.

\section{Management Plans and Initiatives}

- Scrap Metal - The Pollution Prevention Act of 1990, which states that pollution must be prevented or reduced at the source, is a major driver for scrap metal management and has encouraged recycling efforts.

- Scrap Precious Metal - Oak Ridge operates DOE's precious metal recovery program and a central recycling pool for precious metals.

- Equipment - At the start of FY 96, on-site property management systems will move to value-based self-assessment systems, and will be able to better respond to government audits, data requests, and other special requests. 


\section{Associated Vulnerabilities}

- Scrap Metal - Off-site disposal of contaminated scrap metal could create environmental liabilities.

- Scrap Precious Metal - No vulnerabilities specific to scrap precious metal exist.

- Equipment - One site reported that some accountable equipment has long been identified as a major potential issue since any items used in contact with the contents of the high-level radioactive waste underground storage tanks may be classified as dangerous waste under state requirements.

\section{Disposition Options for MIN ScRap Metal and EquipMEnT}

\section{Scrap Metal}

Sale is a preferred and widely used disposition method for clean scrap metal. It is conducted through contracts with vendors via sealed bids or auctions. Waste burial is the usual disposal method for contaminated scrap metal designated as low-level waste (LLW). Eight of the 25 sites evaluated in the MIN Initiative accumulate and store scrap. Five sites, those that have unique treatment or decontamination capability or a unique resource (e.g., LBL's copper inventory), disposition scrap for unrestricted reuse or recycle. Five sites reuse and recycle scrap under certain restrictions.

The Department has used the NEPA process to evaluate disposition options for scrap metal. Last year, the Department's Oakland Operations Offices conducted an environmental assessment (EA) to address the disposition of volumetrically contaminated copper. This EA showed that copper could be safely released even though it was slightly contaminated. The Department's Office of Environment, Safety, and Health approved the EA and released the copper for sale to a scrap dealer for $\$ 247,000$.

\section{Equipment}

Several disposition pathways for equipment in inventory involve reuse. Equipment may be reused on site. A site may make available equipment that is determined to be excess to other DOE sites through the Reportable Excess Automated Property System (REAPS) database. Surplus equipment is made available to other federal agencies for reuse through the General Services Administration (GSA). Through the local Economic Development Program, which was initiated to offset local consequences of Department downsizing, excess equipment may be used to support local economic development projects. The Department may grant equipment to the EnergyRelated Laboratory Equipment Grant Program, which was established by the Department to make used equipment available to educational institutions. Sites may donate surplus personal property to non-federal public agencies and other specifically designated recipients. The Department also sells equipment through auction or sealed bids. The Department dispositions equipment determined to have no value other than as scrap through the same disposition pathways that are used for scrap metal. 


\section{COST INFORMATION}

The MIN Initiative requested cost information from the sites for the following activities: maintaining MIN scrap metal and equipment; addressing environmental, safety, and health vulnerabilities associated with scrap metal and equipment; and implementing the available disposition options. In many cases, cost data were not reported or could not be determined.

\section{Maintenance}

- INEL and Hanford reported annual maintenance costs of $\$ 22$ and $\$ 77$ million respectively, while five other sites reported a range of annual costs from $\$ 8,000$ to $\$ 289,000$. The remaining sites either did not or could not report annual cost data. No cost data were provided for maintaining MIN equipment.

\section{Addressing Environmental, Safety, and Health Vulnerabilities}

- SRS reported a cost of $\$ 2.5$ million to address environmental, safety, and health vulnerabilities. The remainder of the sites either did not or could not determine the associated vulnerability costs. No cost data were provided for the vulnerabilities associated with MIN equipment.

\section{Disposition}

- The Scrap Metal and Equipment Team reported that the scrap metal estimated total asset value (gross revenue) from dispositioning ranges from $\$ 3.3$ to $\$ 84$ million. The Scrap Metal and Equipment Team reported that the equipment estimated total asset value (gross revenue) from dispositioning ranges from $\$ 123$ million to $\$ 1.9$ billion, with middle range estimates between $\$ 220$ and $\$ 950$ million.

\section{Path Forward}

\section{Scrap Metal}

- Finding: Reuse/recycling of contaminated metals within the DOE complex must be increased while limiting the disposal of scrap metal as waste.

Option: Establish Department policy on internal reuse/recycling of radioactively contaminated/activated scrap metal.

Option: Develop a standard decision model for DOE sites to use in making internal recycle versus disposal decisions.

Option: Participate in development of EPA and NRC rules on standards for releasing radioactive materials. 


\section{Equipment}

- Finding: Primary data elements for standardizing equipment-related information and reports must be defined.

Option: Configure existing and future site information management systems to allow for complex-wide consolidation and analysis of equipment information.

- Finding: Identify and quantify equipment for disposition.

ㅇtion: Review, identify, and assign custodianship for all known equipment.

Option: Correlate existing property management information to determine equipment utilization and location.

Option: Develop and implement incentives to optimize equipment levels with planned mission-related activities.

- Finding: Dispositioning avenues for all clean equipment determined to be in excess of DOE requirements must be expedited.

Option: Apply sufficient resources to expedite disposition of excess/surplus equipment using existing mechanisms.

Option: Develop and implement incentives for the property management organizations to disposition excess/surplus equipment.

- Finding: Site goals, project requirements, and contaminated equipment disposition activities must be coordinated.

Option: Expedite contaminated equipment disposition activities for equipment with the highest potential for reuse in contaminated areas.

Option: Identify and evaluate the opportunities for cleaning and reusing "high-value" contaminated equipment. 